MICHAŁ GNATOWSKI

(Białystok)

\title{
NOWE RADZIECKIE DOKUMENTY O POSTAWACH LUDNOŚCI I POLSKIM PODZIEMIU NIEPODLEGLOŚCIO- WYM W REGIONIE BIALOSTOCKIM W LATACH 1940-1941
}

\begin{abstract}
WSTĘP
Publikujemy kolejny zestaw radzieckich dokumentów' o postawach ludności i polskim podziemiu niepodległościowym $\mathrm{w}$ regionie białostockim $\mathrm{w}$ latach 1940-1941. Z 18 publikowanych dokumentów pierwszy nosi datę 1 październik 1940 r., a ostatni - 22 maj 1941 r. Wytworzone one zostały głównie przez służby Zarządu Obwodowego NKWD i Zarządu Obwodowego NKGB w Białymstoku $\mathrm{w}$ wymienionych latach. Jedynie 4 dokumenty wytworzone zostały przez inne służby: prokuratora obwodu białostockiego, Komitet Obwodowy Komunistycznej Partii (bolszewików) Białorusi oraz władze terenowe Białoruskiej Socjalistycznej Republiki Radzieckiej.
\end{abstract}

\footnotetext{
' Por. M. Gnatowski, Problemy SZP-ZWZ w regionie bialostockim w latach 1939-1941 w świetle dokumentów NKWD (NKGB), „Studia Podlaskie”, 1998. L. VIII, s. 227-299 oraz M. Gnatowski, Niepokorna Białostocczyına. Opór społeczny i polskie podziemie niepodległościowe w regionie białostockim w latach 1939-1941 w radzieckich żródłach, Białystok 2001, s. 491.
} 
Publikowane dokumenty dotyczą różnych form społecznego oporu ludności regionu i organizowanego podziemia zbrojnego. Prezentują one punkt widzenia na te kwestie radzieckich służb bezpieczeństwa i władz terenowych. Jaki wynika $\mathrm{z}$ tych dokumentów rozpoznanie oporu i struktur polskiego podziemia $\mathrm{z}$ upływem czasu wzrastało, lecz nigdy nie osiągnęło zakładanych celów i nie było dokładne. Często terenowe struktury Związku Walki Zbrojnej traktowano jako odrębne organizacje nadając im dziwne nazwy, np. "legionierzy" czy "nacjonaliści". Zawarte w zestawie dokumenty mają różny charakter i stopień szczegółowości, wszystkie jednak - $z$ jednej strony - potwierdzają informacje $z$ innych źródeł $o$ istnieniu i aktywnej działalności w regionie polskiego podziemia i $z$ drugiej strony - wzbogacają naszą wiedzę o ówczesnej rzeczywistości, o formach oporu i dokumentują radziecką politykę zmierzającą do sowietyzacji i rusyfikacji zajętych w wyniku zbrojnej agresji wschodnich ziem Polski.

Szczegółową analizę charakteru radzieckich dokumentów i zasady edycji autor przedstawił we wstępie do wcześniej publikowanego zestawu dokumentów na ten temat oraz $w$ innych publikacjach ${ }^{2}$.

Dokumenty publikowane są $w$ języku oryginału, tj. w języku rosyjskim, bez skrótów i zmian pisowni. W końcu dokumentu podana jest jego metryka i miejsce przechowywania oryginału oraz odczytane napisy kancelaryjne i dekretacje.

\section{Wykaz skrótów}

\begin{tabular}{|c|c|c|c|}
\hline $\mathrm{a} / \mathrm{c}$ & $\begin{array}{l}\text { - антисоциалистический } \\
\text { - агентуріый }\end{array}$ & ОУРКМ & $\begin{array}{l}\text { - Областиое управление Рабочо- } \\
\text { крестьянской Милиции }\end{array}$ \\
\hline $6.6 \mathrm{blB}$. & - бывІший & PO & - раиошшый отдел \\
\hline ro & - Городской Отдел & POM & - раионный отдел милиции \\
\hline r.rop. & - город & p.p-H. & - раиоіI \\
\hline д.дер. & $\begin{array}{l}\text { - гражданин } \\
\text { - деревня }\end{array}$ & Рик & $\begin{array}{l}\text { - раионный исполиительный } \\
\text { комитет }\end{array}$ \\
\hline $\begin{array}{l}\text { д.дер. } \\
\text { жел.дор. }\end{array}$ & $\begin{array}{l}\text { - деревня } \\
\text { - железная дорога }\end{array}$ & & - сегодняшний год \\
\hline $\begin{array}{l}\text { зав. } \\
k / p, k-p\end{array}$ & 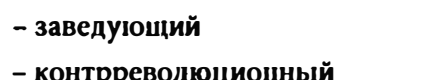 & $\begin{array}{l}\text { coB. } \\
\mathrm{C} / \mathrm{O}\end{array}$ & $\begin{array}{l}\text { - совершенно } \\
\text { - сельский осведомитель }\end{array}$ \\
\hline M.M-Ko & - местечко & c/c, c/сов. & - сельский совет \\
\hline $\begin{array}{l}\text { нач. } \\
\text { HCIII }\end{array}$ & $\begin{array}{l}\text { - начальник } \\
\text { - Неполная средняя школа }\end{array}$ & УРКМ & $\begin{array}{l}\text { - УІравление раиошіого комис- } \\
\text { сариата милиции }\end{array}$ \\
\hline KO, обком & - Областной комитет & 'І.чел. & - человек \\
\hline ОблФО & - Областной финансовый огдел & эКз. & - экземглярь \\
\hline
\end{tabular}

${ }^{2}$ Por. przypis 1. 


\section{Dokument 1}

[1940 październik 1, Bialystok]', - Pismo sekretarza Komitetu Obwodowego $K P(b) B$ w Bialymstoku do Zarzqdu Obwodowego NKWD informujqce o akt ywizacji wrogich wobec władzy kułackich elementów w rejonie monieckim.

№ $1050^{2}$

\section{НАЧАЛЬНИКУ ОБЛАСТНОГО УПРАВЛЕНИЯ НКВД TOB. БЕЛЬЧЕНКО}

Моньковский райком КП(б)Б докладной запиской сообщает Обкому КП(6)Б, что в районе за последнее время активизировались кулацко-враждебные элементы.

1.21 сентября 1940 года, около дер. Негерово, Трестьянского местсовета убит бедняк ДОМКОВСКИЙ.

2. 22 сентября в деревне Пенске бандит Кобеско через окно ударил в голову камнем члена с/совета т. КРУЧЕВСКОГО.

3. В дер. Татары, жена солтуса КРУПОВЕЦКОГО избила члена совета Ядвигу БЕРЖИЛО.

4. 23 сентября гр-н ПОДОЛЕК порезан ножом.

Обком КП(б)Б предлагает срочно принять меры к расследованию всех указанных фактов и результаты сообщить Обкому КП(6)Б к 10 октября с.г.

СЕКРЕТАРЬ БЕЛОСТОКСКОГО

ОБКОМА КП(6)Б БЕЛОРУССИИ:

(С. ИГАЕВ)

Kopia, maszynopis.

'̇ródło: PAOSOG w Grodnie, zesp. 6195, spr. 1, t. 91, k. 445.

${ }^{2} \mathrm{Nr}$ wpisany odręcznie.

${ }^{\text {b }}$ Wielkie litery i podkreślenia oryginału.

1 Datę ustalono na podstawie pisma kierownika Wydziału Organizacyjno-Instruktorskiego KO KP(b)B Siemionowa 2 12.X.1940 r. (Por. dok. 98, w: M. Gnatowski, Niepokorna Białostocczyzna. Opór społeczny i polskie podziemie niepodleglościowe $\mathrm{w}$ regionie białostockim $\mathrm{w}$ latach 1939-1941 w radzieckich źródłach, Białystok 2001, s. 317. 


\section{Dokument 2}

1940 październik 6, Augustów, - Raport kierownika Wydziału Finansowego Rejonowej Rady Wykonawczej Delegatów Ludu Pracującego w Augustowie o okolicznościach zabójstwa agenta skupu W. I. Tichonowa.

6-го октября 1940 года.

тов. КУлИКОВУ.

№ $05 \mathrm{c}$

гор. Августов.

От Зав. Августовским Райфо КОСТИНА М. А.

\section{ДОКЛАДНАЯ 3 АПИСКА}

25-го сентября в 4 часа дня возвращался из дер. Язево - в дер. Могильницы не досекая 200 метров до дер. Могильницы - Могильницкого сельсовета был убит налоговой агент ТИХАНОВ ${ }^{b}$ Василий Иванович. Убийство было произведено на ровном месте в поле.

ІІри налоговом агенте находилось очевидно неболее-3000 руб., все корешки 73-х квитанционных книжек, а также лицевые счета и печать налогового агента. Все то было взято вместе с портфелем. При убитым было найдено 73 р денег и карманные часы, которые остались целые. Убийство было произведено зверски, о чем свидетельствует труп убитого и местность, так как по местности видно, что борьба производилась в 2-х местах.

Агент-ТИХАНОВ ехал на велисопеде по узенькой трапинке около дороги груды камней. Агенту Тиханову был нанесен первый удар камнем в затылок, метров 20-25 от первого места покушения, по направлению к деревни, местность была истоптана свидетельствующая, что сдесь происходила борьба и еще дальше на 10 метров был обнаружен труп агента-Тихонова, у которого были обнаружены - пролом головы и лица в нескольких местах, излом ребер, прострел правой руки и прострел виска с вылетом пули.

Агент-ТИХАНОВ был найден крестьянином дер. Язево, который заявил в сельсовет и через 10-20 минут при явке секретаря Могильницкого сельсовета на места убийства - Тиханов был обнаружен впередсмертных судоргах и чкрез несколько минут скончался.

Агент-Тиханов происходит из бедной крестьянской семьи дер. ГабовоГронды Августовского района Белостокской облости. По национальному 
происхождению русский, хозяйства не имеет. До прихода Красной Армии был пилыцеком по дереву. Семья осталась 7 человек, жена в положении, самому младшему ребенку 2 года и самому старшему 16 лет, который работает по договору в СССР в гор. Владимире.

Агент-Тиханов был исклочительно добросовестный и преданный работник. 20/9-40 года мною было проведено совещание налоговых агентов в кабинете председателя Райисполкома тов. IIIаха, где Тиханов, два брата Ефремовых, два брата Фомины и Антипов - налоговые агенты все с дер. Габове-Гронды ставили вопрос, что им необходимо оружие, так как за последнее время по ихнему адресу сыпались угрозы и анонимные письма, подобные заявления со стороны других налоговых агентов и других были ренее заявления, о чем я стаил в известность Начальника Райотдела НКВД тов. Жыдовского, последний за неимением оружия мою просьбу не удовлетворил.

5, 6 и 7 сентября 1940 года были произведены попытки покушения на налоговых агентов - Ефимова Дмитрия Клавницкого сельсовета, Ефимова Липатея ІІІтабинского сельсовета ${ }^{d}$ и Соболевского - Вулько-Карвовского c/c. Первые двое отбились, а последний отбился взрывчатами самодельными пакетами, бросая их через окно, так как налет был произведен в дом в ночное время, по этому имеются полные основания думать, что налоговым агентам - Штабинского сельсовета Ефимову Липатею, Кольницкого c/c Ефимову Дмитрио, Баргловского сельсовета Фомину и Вулько-Карвовского c/c Соболевскому угрожает прямая опасность, не говоря уже о налоговых инспекторах.

30-го снтября 1940 года мною было проведено очередное совеццание налоговых агентов в Райфинотделе, последния очень настойчево и усильно просили выдать оружие или освободить от работы ввиду явной угрозы.

Я в свою очередь сейчас-же поставил этот вопрос перед НКВД и председателем Рика т. Шаховым ${ }^{d}$, однако по мотивам отсутствия оружия в районе налоговым агентам небыло выдано.

Начинаются нездоровые настроения налоговых агентов, последние требуют увольнения, не смотря на все принятые мною меры к убеждению обстановка осталась напреженной. По этому прошу Вашего содействия в слудующих вопросах:

a) Назначить единовременное пособие семьи ТИХАНОВА.

6) Оказать помоць в назначении персональной пенсии семьи.

в) ІІомочь через областные организации и НКФ БССР преобрести оружие налоговым агентам. 
г) Прошу принять и утвердить расходы связанные с похаронами в сумме 800 руб.

Зав. Августовским Райфо (Костин)

Верно: Начальник 1-го сектора

Облфо

(podpis)

(Лисиков)

Kopia poświadczona, maszynopis.

Żródło: PAOSOG w Grodnie, zesp. 6195, spr. 1, t. 91, k. 453 (obustronna)

- Wielkie litery i podkreślenia oryginału.

'Tak w oryginale. Powinno być: „Tichonow"

"Tak w oryginale. Powinno być: "Żadowski"

${ }^{d}$ Pomyłka. W rejonie augustowskim nie było takiej rady wiejskiej.

e Tak w oryginale.

\section{Dokument 3}

1940 październik 8, Białystok, - Raport specjalny prokuratora obwodu białostockiego o okolicznościach zabójstwa Awgustienki we wsi Wólka rejonu lapskiego.

СЕКРЕТАРЮ БЕЛОСТОКСКОГО ОБКОМА КП(б)Б,

\section{Tов. Иraeвy."}

- Спец. донесение. -

29/IX-40 года в 12 часов ночи в д. Вульни Лапского района имело место убийство грна АВГУСТИЕНКО при следующих обстоятельствах:

В доме гр-на СОКОЛОВСКОГО была организована вечеринка. На вечеринке присутствовала молодеж ряда окрестных деревень и работники совхоза «Каменный двор".

Во время вечеринки между присутствующцими произошла драка, о чем присутствующий агроном совхоза КРУПНЕВ доложил пом.-политу АРАНОВИЧУ. 
Аранович, захватив с собой зараженное двухствольное ружье, явился в дом, где была вечеринка, но т.к. все до этого разошлись, застал там только граждан АВГУСТИНЕНКО и СЛЯНО.

АРАНОВИЧ предложил обоим указанным гражданам поднять руки вверх, а рабочему совхоза ЕЛИСЕЕВУ (пришедшему с ним) обыскать, что он и выполнил, но обнаружено ничего не было.

После личного обыска АРОНОВИЧ предложил АВГУСТИНЕНКОВУ выйти на улицу и после того как последний вышел, произвел по нем два выстрела, которыми он и был убит.

АРОНОВИЧ арестован. Следствие ведется прокуратурой Лапского p-на.-

П Р ОК У Р О Р

БЕЛОСТОКСКОЙ ОБЛАСТИ

$8 / \mathrm{X} 40^{\circ}$

(podpis) (Д У Б Ин ИН).-

Oryginal, maszynopis.

Na dokumencie: $\mathbf{z}$ lewej strony pieczęć firmowa $\mathrm{z}$ napisem $w$ języku rosyjskim: Herb ZSRR, niżej:

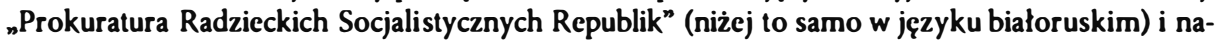
stępnic z prawej strony: ${ }_{n}$ Prokurator obwodu białostockicgo Białoruskiej SRR ${ }^{n}$ i z lewej to samo w języku białoruskim. Na dole data 8 X 1940 i niżej $\mathrm{Nr}$ (nie wpisany), zsyłać się na $\mathrm{nr}$ i datę,

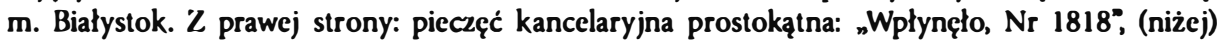
"10/10.1940". W środku adnotacja wpisana ukosem: Spec. Sektor (podkreślone i nieczytelny podpis).

Żródło: PAOSOG w Grodnic, zesp. 6195, spr. 1, t. 91, k. 248.

\footnotetext{
- Wielkie litery i podkreślenia oryginału.

"lak w oryginale. Powinno być: Wólka.

'Data wpisana odręcznic.
} 


\section{Dokument 4}

1940 październik 9, [Bialystok], - Informacja Kierownika Wydziału Finansowego Obwodowej Rady Wykonawczej Delegatów Ludu Pracującego w Bialymstoku o zabójstwie w rejonie augustowskim agenta skupu W. I. Tichonowa.

копия

Секретно. ${ }^{\mathrm{a}}$

Областной Финан-

совый отдел

Белосток, 9/X-40г.

№ $73 c^{\mathrm{b}}$

\section{СЕКРЕТАРЮ ОБКОМА КП(б)Б}

тов. ИГАЕВУ

При сем прилагаю копию докладной записки зав. Августовского райФО тов. КОСТИНА по вопросу убийства и ограбления налогового агента т. ТИХОНОВА.

Прошу ваших указаний на имя РК КП(б)Б Августовского района об оказании помощи Августовскому райфо в связи с создавшимся положением и настроениями налоговых агентов, а также об установлении пенсии семье погибшего.

Сообщаю, что похороны т. ТИХОНОВА приняты на счет госбюджета и мной сделано распоряжение о выдаче семье погибшего единовременное пособие в размере 500 рублей.

ПРИЛОЖКЕНИЕ: УПомянутое на 1 листе.'
ЗАВ. ОблФО -
Верно: (podpis nieczytelny)c
(КУлИКОВ)

Kopia poświadczona, maszynopis.

Zródło: PAOSOG w Grodnie, zesp. 6195, spr. 1, t. 91, k. 453.

\footnotetext{
- Podkreślenia i wielkie litery oryginału.

${ }^{b} \mathrm{Nr}$ wpisany odręcznie.

' Poświadczenie wpisane odręcznie.

' Por. dok. 2.
} 


\section{Dokument 5}

1940 październik 15, [Bialystok], - Pismo naczelnika Zarzq̨du Obwodowego NKWD w Bialymstoku do Sekretarza Komitetu Obwodowego KP(b)B informujqce o poleceniu wydawania broni akt ywowi partyjnemu i radzieckiemu w zwiazku $z$ zabójstwem agenta handlowego Tichonowal.

Ha № 1070 or $10 / X$.

Сов Секретно."

Секретарю Белостокского Обкома КП(б)Б.

Тов. Киселеву.

На основании фактов сообщеннных Зав. Августовским Райфо тов К о с т и н ы м, в отношении обстоятельств предшествовавших убийству налогового агента $\mathrm{T}$ и $\mathrm{x}$ о н о в а Василия Ивановича мною дано указание начальнику Августовского РО НКВД Жадовскому, о выдаче в необходимых случаях, вполне проверенным товарищам из партийно-советского актива, оружия для самозащиты, из трофейных запасов.

Нач УНКВД по Белостокской обл.

$$
\text { (podpis) (Бельченко) }
$$

15 октября $40 \mathrm{r}$.

№ $1165 /$ эKO $^{\mathrm{b}}$

Oryginał, maszynopis.

Na górze dokumentu pieczęć kancelaryjna: „Wpłynęło, 17/X 1940” (data wpisana odręcznie).

'̇ródło: PAOSOG w Grodnie, zesp. 6195, spr. 1, t. 91, k. 456.

a Podkreślenia i druk rozstrzelony oryginału.

${ }^{b}$ Dzień i nr wpisane odręcznie.

' Por. dok. 2 i 4. 


\section{Dokument 6}

1940 grudzień 15, Bialystok, - Raport specjalny nr 2 Zarzqdu Obwodowego NKWD w Bialymstoku o przebiegu wyborów do rad terenowych w obwodzie.

\section{СЕКРЕТАРЮ БЕЛОСТОКСКОГО КІІ(б)Б}

\section{тов. ПОПОВУ. \\ r. Белосток.}

С II Ц ЦО О БЩЕНИЕ № 2 .

На 12 часов 15 декабря 1940 года.

Выборы по области проходят нормально. В среднем по районам нам на 10 часов утра проголосовало 40-50\%, по городу Белостоку $25 \%$.

ПОЛОЖИТЕЛЬНЫЕ ФАКТЫ: В Едвабновском районе в РО, явилось 6 челювек участников контрреволюционной организации "СВБ» с «повинной» заявлением о желании участвовать в выборах.

В Августовском районе деревни Жерих - ВИЛЬЧЕВСКИЙ Есигний Леонтьевич, 80 лет, явился на участок первым, с заявлением о желании голосовать за тов. СТАЛИНА.

В дер. Ясвитая, старуха - МОСТОВСКАЯ, 105 лет, и ЖЕЛИХОВСКАЯ, 90 лет, отказались от подвод, предоставленных им и пешком явились на избирательный участок для голосования.

ОТРИЦАТЕЛЬНЫЕ ФАКТЫ: В Замбровском районе, на избирательном участке Кольновского сельсовета на 8 часов утра не было ниодного избирателя, а на 10 часов - 50 избирателей. На место выехал Секретарь РК КП(6)Б и Начальник РО НКВД.

В районном центре Кольно на избирательном участке № 3 на 10 часов утра из 1080 избирателей проголосовало 80 человек. ІІричины выясняются.

В Волковысске в бюллетене кандидата в Горсовет - УШАКОВ Владимир Александрович - напечатано Алексеевич. Бюллетень срочно перепечатывается. Голосование продолжается.

ПРОИСШЕСТВИЯ: В гор. Августове, при утреннем обходе, обнаружена листовка антисемитского характера, написанная от руки наклеяанная на частном доме. 
Следствие ведет РО НКВД. Других происшествий не зафиксировано.

\section{НАЧАЛЬНИК УНКВД БЕЛОСТОКСКОЙ ОБЛАСТИ (МИСЮРЕВ)}

15 декабря 1940 года ${ }^{b}$

№

гор. Белосток.

Oryginal, maszynopis.

$\mathrm{Na}$ górze dokumentu z lewej strony adnotacja: „Zapoznać kier. Wydziału OrganizacyjnoInstruktorskicgo, Popow., 15.XII.40 r., M.in. podpis Siemionowa.

'̌ródło: PAOSOG w Grodnie, zesp. 6195, spr. 1, t. 92, k. 213-214.

- Wielkie litery i podkreślenie oryginału.

${ }^{b}$ Dzień wpisany odręcznie.

\section{Dokument 7}

1940 grudzień 19, [Bialystok], - Raport pisemny Zarzq̨du Obwodowego NKWD $w$ Bialymstoku $z$ przebiegu wyborów do rad terenowych w obwodzie.

№ 2719

$20 / \mathrm{XII}^{*}$

Сов.Секретно

СЕКРЕТАРЮ БЕЛОСТОКСКОГО ОБКОМА КП(б) БЕЛОРУСИИ

тов. ПО ПО В $\mathrm{y}^{\mathrm{b}}$

ДОКЛАДНАЯ 3 А П ИСКА

О6 итогах выборов депутатов в местные Советы по

Белостокской области. 
Выборы депутатов в местные Советы прошли при болышем политическом под’еме трудящихся масс.

Участие избирателей в голосовании:

В Областной Совет составили $99,66 \%$

“ Городские Советы “ “ 99,37\%

“ Районные Советы “ 99,53\%

“ Поселковые и сельские Советы 99,64\%

Из общего количества участвующих в голосовании подало голосов за кандидатов:

$\begin{array}{ll}\text { В Областной Совет } & 99,19 \% \\ \text { “ Городские Советы } & 99,25 \% \\ \text { “ Районные Советы } & 99,07 \% \\ \text { “ Поселковые и сельские Советы } & 98,53 \%\end{array}$

Таким образом все намеченные кандидаты в депутаты местных Советов избраны.

Активность трудящцихся масс характеризуется не только участием в голосовании, но множествами фактов проявления высокого патриотизма. Как например:

«По 4 избирательному округу Ленинского избиратульного участка гор. Белостока, вместе с бюллетенем была опущена записка следующего содержания:

Люблю свою родину-ласкувую мать.

Готов за нее свои силы отдать!

Люблю свой чудесный могучий народ, который культуру себе создает.

За свободу спасибо, Вам СТАЛИН отец

Конституции нашей великий Творец,

Ты знямя свободы и символ побед,

Подарю я тебе самый лучший букет.

Голосую за счастье, за светлые годы,

Голосую за Вас дорогие народы, 
За отца, за детей, за любимую мать,

Решил Вам трудами букет свой создать.

(Избиратель «В» 6 час. 25 минут).

"Ilo 5 избирательному округу гор. Белостока на бюллетене написано: «Голосую за Советскую власть, мы с радостыо живем и довольны Советской властыо, пусть живет и крупнет наша родина, если нужно врагов душить и если моя помощь понадобиться, то я помогу, хотя мне уже 71 год (КАЧАНОВ).

«В Калиновский избирательный участок Кнышенского района, явилась избирательница ЛИВАЙКО Марьяна, которая опуская в урну бюллетень заявила:

«При польском правительстве я право на голосование не имела и не хотела иметь, тогда только голосовали за богатых, а теперь я дождалась той счастливой минуты, когда могу отдать свой голос за таких людей, как я сама».

В Бельском районе на избирательный участок первыми за час до начала голосования пришли братья дер. Гробовец КРАСОВСКИЙ Дмитрий Степанович 53 лет, и КРАСОВСКИЙ Федор Степанович 61 год, которые опуская бюллетени в урны воодушевленно заявили, голосуем за СТАЛИНА, за РОДИНУ».

В Августовском р-не дер. Жерих на участок первым явился ВИЛЬЧЕВСКИЙ Есигней с заявлением о желании голосовать за товарища СТАЛИНА.

С дер. Ясвитая этого же района МОСТОВСКАЯ старуха 105 лет и ЖЕЛЕХОВСКАЯ старуха 90 лет отказались от подвод представленных им и пешком явились на избирательный участок для голосования.

В результате принятых агентурно-оперативных мероприятий в отдельных районах скрывавшиеся и находившиеся на нелегальном положении участники контрреволюционно-повстанческой организации «Союз Вооруженной борьбы» стали частично являться с «повинной». 
В день выборов 15 декабря 1940 года в Едвабновское РО НКВД явились 6 участников повстанческой организации "СВБ" с заявлением о прекращении борьбы с Советской властью и о своем желании участвовать в выборах. Один из явившихся с - «повинной» БУЧИНСКИЙ Станислав заявил:

«Я сейчас иду на избирательный участок и проголосую первый».

Аналогичный случай имел место в гор.Белостоке - явки 3 человек повстанцев С «повинной».

Всего в Едвабновском р-не за время избирательной кампании явились с «повинной» 78 человек участников контрреволюционной повстанческой организации из них 8 комендантов организации.

В Белостокском р-не явились с «повинной» 19 человек, ранее скрывающихся участников организации

На ряду с огромной политической и организационной работой проведенной партийными организациями, в день выборов выявилось значительное количество организационных недостатков как например:

«В Бельском р-не бюллетени кандидатов были завезены в другие участки, где они не боллатировались.

В избирательном участке № 7 Крынковского района 14 декабря избирателям вместо пригласительных повесток для явки на выборы были вручены бюллетени, которые потом собирались обратно, на этом же участке в день голосования бюллетени голосующим выдавались без проверки и пред'явления документов.

В Гняздовском избирательном участке Снядовского р-на была искажена фамилия выдвинутого кандидата вместо ТЫМИНСКОГО было напечатано ЛУКАШЕВИЧ.

В Волковысском р-не на бюллетене кандидата в Райсовет УШАКОВА было написано вместо действительного отчества Алексеевич - Александрович

В гор.Ломже бюллетени кандидатов в депутаты Горсовета были напечатаны только на польском языке в результате во время 
голосования на отдельных бюллетенях были надписи по русски, ничего не понимаю.»

«В Голынском избирательном участке Сопоцкинского района баллатировался ЯРМУСИН Юзеф Мартынович, а в бюллетене значился Иван Мартынович, в связи с этим 25 избирателей не голосовали, заявляя мы за того не голосуем, никто нам о нем не говорил.

На избирательном участке в дер. Трофимовка в кабинах (Соколковский р-н) на стенах висели иконы и в углу одной из кабин стояла статуя иконы (председатель избирательной комиссии член вЛКСМ СОРОКИН).

В Рагеницком избирательном участке Ломжинского р-на продукты из буфета организованного Сельпо отпускались только по запискам председателя с/с КОЛЕСИНСКОГО, что вызвало законное нарекание со стороны избирателей.

Деятельность контрреволюционного элемента в предвыборные и выборные дни была направлена на активную агитацию среди населения за отказ голосовать за выставленных кандидатов, вычеркивание кандидатов на бюллетенях, что подтверждается количеством бюллетеней признанных не действительными, а именно:

В Областной Совет признано не действит. 167 6.зачерк.фамилии 6.954

$\begin{array}{lrrrr}\text { “ Горсоветы } & \text { “ } & \text { “ } & 31 & 1.844 \\ \text { “ Райсоветы } & \text { “ } & \text { “ } & 196 & 6.390 \\ \text { “Поселковые } & \text { “ } & \text { “ } & 231 & 9.004\end{array}$

Конкретно агитация контрреволоционного элемента выразилась в следуюгцем:

В Крынковском р-не зарегистрировано 20 случаев отказа голосовать, среди них члены семей репрессированных, “Бодачи». ДЖЕКО Мария из дер. Масляны 14 на предвыборном собрании заявила, я сама не пойду голосовать и Вам не советую, потому что в кабины пускать не будут, они знают, что мы будем голосовать против и зачеркивать их кандидатов, поэтому не стоит вообце ходить на их голосование. 
В дер. Плютичи Бельского р-на группа баптистов 7 человек (ИВАНЮК Мартын, ПЕТЕРСОН В. ВАСИЛЮК В. и др.) отказались идти голосовать об'ясняя запрецением якобы религиозного обряда указанное богом.

15 декабря во время выборов на избирательном участке № 7 гор. Белостока сотрудником ОУ РКМ СЕРГЕЕВЫМ в корридоре участке найдена контрреволюционная листовка следующего содержания:

\section{"Всем е в рея м!}

Дай бог, чтобы Вам голосовать не довелось, чтобы Вас всех халера подушила. Прибыли в Польшу, как свиньи грязными, так что за Вами пыль поднимаеться, а через штанину будет по ногам шоколад течь.

Ох Вы татарские жены и еврейские паршивые морды, мы все идем голосовать не добровольно, а принудительно, ибо знаем, что нас ожидает (арест) помни еврей, ты в польской стране, тебя сюда прислала твою беспризорная доля, что из моей памяти твоя морда не исчезнет, будет бить твой горбатый нос. ІІошлите это к самому СТАЛИНУ (при этом следуют оскорбительные слова).

На оборотной стороне листовки нарисована карикатура.

МЕРОПРИЯТИЯ: ІІриняты меры выявления автора.

«В избирательном участке № 6 г. Белосток на бюллетене была надпись "Долой коммунизм".

В Макаровском избирательном округе Крынковского р-на на бюллетене было написано «Голые, босые, голодные, идем на выборы, могилыциков хорошей польской пролетарской жизни.

На другом бюллетене этого же округа было написано «После выборов 1939 г. начали налагать великие податки (налоги) деньгами и разными культурами и вывозить на белые медведи. А как дальше будет.» «На избирательном участке село Рудка Брянского р-на была надпись на бюллетене кандидатуры в депутаты местного Совета «Польска еце не сгинела.

На избирательном округе № 47 г. Белостока на бюллетене была зачеркнута кандидатура и написано «Прочь с жидами» на втором 
бюллетене этого же округа на польском языке было написано «Прочь коммунизм.»

МЕРОПРИЯТИЯ: Авторы выявляются.

«Ксендз Снядовского костела сам не пошел голосовать и не допустил своих прислуг, когда принли представители окружной избирательной комиссии, последних не пустили в дом не открыв им двери.»

В Кнынинском р-не ксендзы Кнышинского и Крыпновского костелов в день выборов призвали верующих собравнихся в костеле всем принять участие в голосовании, закончив молебень раныше обычного времени сами первые явились на избирательные участки получив бюллетени не заходя в кабины опустили их в урны.

НАЧАЛЬНИК УНКВД ПО БЕЛОСТОК. ОБЛАСТИ ПОЛ К О В Н И К (podpis)

(А. МИСЮРЕВ) 19/XII-1940 r.

№ 2546/2

Отп. В 4-х экз

I. адресату

I. Обкому КП(б)Б

I. в секретариат

I. в 1-м Отд-нии.

Oryginal, maszynopis.

"Yródło: PAOSOG w Grodnie, zesp. 6195, spr. 1, t. 92, k. 225-235.

a $\mathrm{Nr}$ i data wpisane odręcznie.

b Podkreślenia i wielkie litery oryginału.

' Dzień i nr wpisane odręcznie. 


\title{
Dokument 8
}

1941 styczeń 3, Bialystok, - Informacja naczelnika Oddziału Transportowego NKWD Białostockiego Węzła Kolejowego o zlikwidowaniu podziemnej 5 osobowej grupy.

\section{Секретно. \\ Только лично. \\ СЕКРЕТАРЮ БЕЛОСТОКСКОГО ОБКОМА КПбБ \\ тов. ПОПОВу.а}

\author{
СССР \\ НАРОДНЫЙ КОМИССАРИАТ \\ В Н У Т Р Е Н Н Х ДЕ ІІ \\ Главное Транспортное Управление \\ Дорожно-Транспортный отдел \\ Белостокской жел. дор. \\ 3/I 1941 r. \\ № $22^{b}$ \\ гор. Белосток
}

С 30 на 31/XII-40г. УНКВД и нами ликвидирована контрреволюционная террористическая группа в составе 5-ти человек, в том числе и часть транспортников.

Участники боевой террористической группы дали показания, что они ставили задачей совершение терактов путем убийства коммунистов, как по городу, так и на транспорте.

31/XII-40г. посуществу изложенногомноюличнобыл проинформирован нач. ПІодора тов. ВОЛКОВ с целью усиления охраны на ряде об'ектов под новый год, путем обеспечения присутствия коммунистов и т. п. Однако несмотря на всю важность вопроса, со стороны нач. Подора ВОЛКОВА не только не было принято никаких мер, а наоборот, при прямом его участии на стахановском вечере в честь нового года, были допущены факты пьянства, хулиганства со стороны целого ряда коммунистов, работающих в Подоре и Управлении дороги, что подтверждается материалами в справке при сем прилагаемой. Усуглубляется это положение еце и тем, что участники к. р. организации намечали провести свою гнусную работу под новый год, мотивируя тем, что все будут повеселе, подоют и. т. д, поэтому я особенно остро ставил вопрос перед нач. ІІодора т. Волковым. ${ }^{c}$ 
ПРИЛОЖЕНИЕ: - Справка. ${ }^{1}$

НАЧАЛЬНИК ДТО НКВД БЕЛОСТОК. Ж.Д. КАПИТАН ГОСБЕЗОПАСНОСТИ

(ЗЕЛЕНИН) (podpis)

Oryginal, maszynopis.

Na górze dokumentu z prawej strony pieczęć kancelaryjna: ${ }_{n}$ Wpłynç̨o, $\mathrm{nr}$ i data wpisane odręcznie: $3 / I, 1941$.

Źródło: PAOSOG w Grodnic, zesp. 6195, spr. 1, t. 188, k. 22.

a Podkreślenia i wielkie litery oryginału.

"Data i nr wpisane odręcznic.

' Ostatnie zdanie napisane odręcznie.

' $W$ teczce brak załącznika.

\section{Dokument 9}

1941 styczeń 17, Bialystok, - Informacja naczelnika Zarzqdu Obwodowego NKWD w Białymstoku o aresztowaniu w Kowalewszczyźnie Franciszka Markowskiego.

Совершенно секретно.

СЕКРЕТАРЮ БЕЛОСТОКСКОГО ОБЛАСТНОГО КОМИТЕТА КП(б)Б

товарищу К У ДР Я Е В У.

3 десь .

11-го января 1941 года Лапским РО НКВД в деревне Ковалевщизна Пшельчинского сельсовета установлен и задержан МАРКОВСКИЙ Франц Иосифович, 1912 г. рождения, поляк, кулак, бывший полицейский. 
При подходе оперативной группы к дому МАРКОВСКОГО Франца, последний пытался скрыться в направлении леса, но был пойман.

На месте задержания МАРКОВСКОГО было обнаружено и из'ято: 1 пероксилиновая шашка, пистолет «Браунинг» за № 908932 с пятью патронами.

По имеющимся в Лапском РО агентурным данным, МАРКОВСКИЙ Ф. И. 25 мая 1940 года, на общем собрании в д. Ковалевщизна агитировал население не продавать мяса государству.

Задержанный затребован в 3-й Отдел УНКВД для дальнейшего следствия.

\section{НАЧ. УНКВД ПО БЕЛОСТОКСКОЙ ОБЛ.}

(МИСЮРЕВ) (podpis)
17 января 1941 г.
№ $\underline{3 / 272^{b}}$
г. Белосток

Отпеччатано 3 экз.

1-й экз. Наркомвнудел БССР

2-й “ Секрет. Обкома КП(6)Б

3-й “ в дело 3 Отдела.

Oryginal, maszynopis.

$\mathrm{Na}$ górze dokumentu, z prawej strony prostokątna pieczęć kancelaryjna: „Wpłynęło, $\mathrm{nr} 146^{\text {” }}$ i niżej: .18/I, 1941" (Nr i data wpisane odręcznie).

Z lewej strony: nieczytelny podpis.

Źródło: PAOSOG w Grodnie, zesp. 6195, spr. 1, t. 188, k. 98.

a Podkreślenia i wielkie litery oryginału.

${ }^{b}$ Dzień i nr wpisane odręcznic.

\section{Dokument 10}

1941 styczeń 30, Bialystok, - Raport specjalny Zarzq̨u Obwodowego NKWD obwodu białostockiego z przebiegu sprawy agenturalno-śledczej „Buntownicy”. 


\title{
СОВEPШЕНHO СEKРETHO.
}

СЕКРЕТАРЮ БЕЛОСТОКСКОГО ОБКОМА КП(б)Б.

\section{тов. КУДРЯЕВУ,}

г. Белосток.-

\author{
С П Е Ц С О Б Щ Е Н Е
}

по агентурно-следственному делу «БУНТОВІЦИКИ»

по состоянию на 1/II-1941 года.

В начале августа 1940 г., на территории Моньковского района Белостокской области вскрыта и ликвидирована контрреволюционная повстанческая группа, руководимая бывшим капралом польской армии - ЯВОРСКИМ Антоном Францевичем.

В результате агентурно-следственных мероприятий установлено, что эта контрреволюционная повстанческая группа есть одна из ответвлений повстанческой организации, созданной ЛИПКО Яном.

В январе месяце 1941 г. на территории Моньковского района была снята другая контрреволюционная повстанческая группа тесно связанная с группой ЯВОРСКОГО во главе с ШУМСКИМ Станиславом и КУХАРСКИМ Владиславом.

По состоянию на отчетный период по обоим к/p повстанческим группам арестовано 20 человек. Кроме известных по предыдущим сообщениям, дополнительно арестованы:

1. ШУМСКИЙ Станислав Янович, 22-х лет, поляк, уроженец дер. Старое-Долистово, Моньковского района, из кулаков.

2. КУХАРСКИЙ Владислав Петрович, 19 лет, поляк, уроженец гор. Тоганрога, из крестьян-середняков, проживал в деревне Ново-Долистово, Моньковского района.

3. ВАЛУШКО Чеслав Михайлович, 22-х лет, поляк, житель дер. НовоДолистово, Моньковского района.

4. ОРЛОВСКИЙ Петр Степанович, 19 лет, поляк, житель хутора НовоДолистово, Моньковского района. 
Кроме того привлечено к следствию ранее арестованные по другим преступлениям, но активно проходящие по данному делу:

1. МИКУТА Иван Адольфович, 28 лет, поляк, житель дер. ДолистовоНовое, Моньковского района.

2. КИСЛО Эдвард Матвеевич, 28 лет, поляк, кулак, житель дер. СтароеДолистово, Моньковского района.

3. ГАРАБУРДА Игнат Игнатьевич, 1918 года рождения, поляк, уроженец дер. Ясиново, Августовского района.

В процессе следствия, арестованный ЯВОРСКИЙ показал, что он является руководителем контрреволюционной повстанческой организации на территории Старо-Долистовского сельсовета, Моньковского района. В контрреволюционную организацию завербован РАХВАЛЬСКИМ (один из руководителей "Ботальона смерти", находится на нелегальном положении) в январе 1940 года.

При вербовке Яворского, Рахвальскийь об'яснил, что - “Уже существует украинская националистическая организация с центром в гор. Кракове и с филиалом в гор. Львове. Задача этой организации заключается в том, чтобы отделить Украину от СССР и при помоци Германии организовать Украинское государство.

...Кроме того будет организована белорусская националистическая организация с теми-же задачами, что и украинская».

(Из показаний ЯВОРСКОГО от 16/1-41 г.)

После чего РАХВАЛЬСКИЙ присвоил ЯВОРСКОМУ псевдоним «ЕЖ РЫІШАРД" и поручил вербовать в состав организации новых людей и быть ее руководителем на территории Старо-Долистовского сельсовета. Кроме этого РАХВАЛЬСКИЙ обязал ЯВОРСКОГО установить связи с повстанческой организацией в гор. Августове.

Выполняя задание РАХВАЛЬСКОГО, ЯВОРСКИЙ завербовал в состав организации:

1. ВАЛУІІКО Валерьяна, жителя дер. Посвяны, Моньковского района, бывшего секретаря гмины.

2. КОЛЕНДО Станислава, жителя дер. Старое-Долистово, Моньковского района, кулак.

3. СКИЩИМА Ивана ІІимоновича, жителя дер. Старое-Долистово, последнее время работал начальником пожарной команды. 
4. КОЗЛОВСКОГО Казимира, жителя дер. Ясиново, Дембовского сельсовета, Августовского района.

5. РУДСКОГО, жителя дер. Тайно-Старое, Августовского района.

6. ЛЕВДАНСКОГО Александра, поляк, директор школы, дер. Бродень, Моньковского района.

От завербованных была взята присяга. Всем завербованным было дано задание на производство новых вербовок.

Одновременно с вербовкой в контрреволюционную повстанческую организацию указанных выше лиц, ЯВОРСКИЙ установил связь с созданным РАХВАЛЬСКИМ другим филиалом к/р повстанческой организацией КОСАКОВСКИМ. В мае 1940 г. после бегства КОСАКОВСКОГО за границу, ЯВОРСКИЙ установил связь с заместителем КОСАКОВСКОГО - КОВАЛКО Антоном.

О деятельности КОВАЛКО и его группы ЯВОРСКИЙ показал: "13/VI-40 г. ко мне на квартиру приехал КОВАЛКО Антон, который рассказал следующцее, что заместителем в повстанческой организации, руководимой КОСАКОВСКИМ, является он, КОВАЛКО и что им проводится вербовка новых членов в организацию, но не назвал фамилии завербованных».

В вопросе о количестве членов организации, КОВАЛКО сообщил ЯВОРСКОМУ:

«...в его организацию завербовано 16 человек и что он имеет 6 карабинов, револьвер и патроны»

КОВАЛКО Антон находится на нелегальном положении и до сих пор не розыскан.

Кроме контрреволюционной повстанческой организации КОВАЛКО, ЯВОРСКИЙ назвал еще две организации существующие в Моньковском районе.

Касаясь вопроса о этих организациях, ЯВОРСКИЙ показал:

«На ряду с контрреволюционной повстанческой организацией, руководимой мною в дер. Старое-Долистово, еце суцествовала террористическая организация, руководимая IШУМСКИМ Станиславом при участии которого был убит ВАЛУІШКО Казимир. Кроме этого была повстанческая организация руководимая КИСЛО Эдвардом». 
По вопросу о существовании других контрреволюционных повстанческих групп на территории Моньковского района заместитель ЯВОРСКОГО - КОЛЕНДО Станислав на допросе от 13/1-41 г. показал:

«Не помню в каком месяце, но весной 1940 г. мне мельник КОЛЕНДО Станислав Петрович предлагал вступить в их организацию и сказал, что ей руководит ШУМСКИЙ С., но не сказал какие цели преследует их организация. Я от вступления отказался, так как я уже состоял в повстанческой организации ЯВОРСКОГО».

Допрошенный арестованный руководитель третьей повстанческой организации ШУМСКИЙ Станислав Янович 18-го января 1941 г. показал: "Я с 6-го мартя 1940 г. являлся участником контрреволюционной повстанческой организации существовавшей на территории СтароДолистовского сельсовета, Моньковского района в которую был завербован ЯНИКОМ Казимиром... При вербовке в повстанческую организацию ЯНИК мне псевдонима не дал и вместо присяги взял с меня честное слово на верность организации... После вербовки в контрреволюционную повстанческую организацию, мне дал задание проводить вербовку новых лиц... Выполняя задание ЯНИКА... в повстанческую организацию мною были завербованы следующие:

1. ВАСИЛЕВСКИЙ Эдвард Адольфович, примерно 22-х лет, проживал в дер. Долистово-Старое. В данное время находится на службе в Красной Армии, завербован мною в конце марта 1940 г...

2. КУХАРСКИЙ Владислав, отчества не знаю, примерно 20 лет, проживает в дер. Долистово-Новое, арестован вместе со мной, завербован также в конце марта м-ца 1940 г...

3. КОЛЕНДО Станислав, отчества не знаю, примерно 35-ти лет, проживает в дер. Долистово-Старое на мельнице, завербован мной в конце марта 1940 г...»

«...На предыдущих допросах, - показал ШУМСКИЙ - я от следствия скрыл завербованных мною в повстанческую организацию - ОРЛОВСКОГО Петра Степановича, примерно 19 лет, проживает на хуторе Старое-Долистово, ВАЛУШКО Чеслава, отчества я его не знаю, примерно 22-х лет, что живет в Ново-Долистове».

«Кроме лиц завербованных мною в повстанческую организацию, - показал далее ШУМСКИЙ - участниками организации являлись: 
1. ЕКА Зигмунд, отчества не знаю, примерно 40-45 лет, проживает в дер. Долистово-Старое. В повстанческую организацию был завербован мельником КОЛЕНДО Станиславом в апреле 1940 г. и был включен в мого пятерку.

2. СКИІЦИМ Иван ІІІимонович, проживает в дер. Долистово-Старое, которого я вербовал в свою организацию в апреле м-це 1940 г., но он мне заявил, что является членом другой повстанческой организации, но не сказал в какой и кем завербован».

Касаясь своей роли в контрреволюционной повстанческой организации и задач этой организации ШУМСКИЙ показал:

«В дер. Долистово-Старое я являлся руководителем организации, которая ставила задачу свержения Советской власти на территории Западных областей Белоруссии, путем вооруженного восстания».

Кроме работы по вербовке новых членов, повстанческие организации ставили и другие задачи - выявления оружия, проведения террористических актов над советским активом и сбора шпионских сведений.

ІІо вопросу сбора оружия обвиняемый ЯВОРСКИЙ в своем показании от 9/1-41 г. сообщил:

«Примерно в январе 1940 г., разговраивая с РАЧКОВСКИМ (РАЧКОВСКИЙ быв. директор молочного завода в дер. Долистово) на политические темы, я задал вопрос ему, как бы он поступил еслибы кто-либо предложил ему встепить в повстанческую организацию, на что мне РАЧКОВСКИЙ ответил, что вступил бы и помог в работе этой организации. В этот раз я ему предложил узнать у кого и сколько имеется оружия и доложить мне. Через несколько дней РАЧКОВСКИЙ это задание выполнил и доложил мне списки лиц у кого какое имеется оружие:

1. ЕКА Зигмунд имеет пулемет.

2. МАЛИШІЕВСИЙ, но не назвал имени, должен имет карабин.

3. РАДИВОН Петр имеет один карабин.

4. АНДРАК Антон имел один пулемет, но сдал органам Советской власти.

Кроме того самим РАЧКОВСКИМ спрятан пулемет на подлавке школы в дер. Долистово-Старое и несколько карабинов. А также у себя РАЧКОВСКИЙ имеет карабин и револьвер" 
Местонахождение оружия выясняем - для из'ятия.

По вопросу о террористических и диверсионных актах и намерениях организации и ее членов ЯВОРСКИЙ показывает:

«...КОВАЛКО мне рассказал, что он намеревался бросить гранату

в помещение Участковой Избирательной комиссии по выборам

в Верховные Советы СССР и БССР, но ему это сделать запретил КОСАКОВСКИЙ. После чего КОВАЛКО А. спросил меня, что делать с людьми которые идут против поляков и о всем доносят Соввласти?. Я ему ответил на это вопросом, чтобы с ними сделал? КОВАЛКО ответил, что таких людей нужно убивать»

Касаясь дальнейшего разговора с КОВАЛКО, ЯВОРСКИЙ показывает: "Как мне помнится КОВАЛКО назвал мне ряд фамилий, которые доносят Советской власти, но сейчас вспомнить я их не могу... Вспоминаю одну фамилию названную КОВАЛКО Антоном - это житель дер. Ясвилы по фамилии КОВАЛКО, имени его не знаю к которому КОВАЛКО Антон хотел бросить гранату в комнату во время его сна ночью, но я КОВАЛКО Антону этим заниматься запретил и сказал, что задача нашей повстанческой организации - не совершение террористических актов, а подготовка масс к вооруженному восстанию против Советской власти за восстановление быв. панской Польши.»

В июне месяце 1940 года в районе дер. Ново-Долистово был убит комсомолец активист, житель этой деревни - ВАЛУУШКО Казимир. Проведенные В. то время агентурно-оперативные мероприятия не вскрыли действительных виновников этого убийства. Арестованный участник убийства КУХАРСКИЙ был вскоре освобожден из-за недостатка улик и завербован в агентурную сеть Райотделения. Второй участник МИКУТА несмотря на неопровержимые улики в убийстве не сознался. Дело на последнего было закончено и направлено на Особое Совещание.

В процессе следствия по делу арестованных указанных выше контрреволюционных повстанческих организаций, удалось установить, что убийство ВАЛІУІШКО Казимира является делом этой организации.

Арестованный ЯВОРСКИЙ в своем показании от 9-го января 1941 г. на вопрос, кто совершил террористический акт над ВАЛУШКО Казимиром? - ответил: 
“...ВАЛУШКО Казимир, житель дер. Ново-Долистово, Моньковского района, был убит в июне 1940 г., как мне говорил КОЛЕНДО Станислав... КУХАРСКИМ Владиславом, проживает в дер. НовоДолистово и принимал в этом участие ШУМСКИЙ Станислав и МИКУТА, имени не знаго, первый прож. в дер. Старое-Долистово, второй в дер. Новое-Долистово, Моньковского района. Участие в спратании трупа ВАЛУШКО принимал СКИЩИМ Иван ІІІимонович».

Арестованный КУХАРСКИЙ по поводу террористической деятельности организации 18-го января 1941 г. показал:

«Примерно в середине марта 1940 г. в разговоре ХРОСТОВСКИЙ передо мной поставил задачу борьбы с сельским активом, путем террора, как он выразился, нужно убивать всех поляков, которые активно помогают Советской власти»

Конкретизируя эту задачу КУХАРСКИЙ далее показал: "ХРОСТОВСКИЙ вопрос о терроре над партийно-советским активом в первую очередь из местного населения, рассматривал как первостепенную задачу деятельности организации. ХРОСТОВСКИЙ говорил, что всех поляков и лиц других национальностей из местного населения, которые активно помогают Советской власти и особенно тех, которые могут выдать Советской власти участников повстанческой организации и других лиц, скрывающихся от Советской власти, необходимо немедленно убивать.

Террор над активистами должен проходить систематически и так, чтобы не оставалось следов, для розыска совершивших убийство. Убивать активистов нужно на дорогах, в лесах и трупы их тщаательно прятать.

В конце мая 1940 г. ХРОСТОВСКИЙ пришел к коменданту пляцувки в дер. Долистово-Новое - РАДИОНУ Петру Шимоновичу. Вместе с ним они пришли ко мне на квартиру. В беседе РАДИОН доложил ХРОСТОВСКОМУ о том, что в деревне ДОЛИСТОВО-НОВОЕ имеется группа крестьян, которая активно помогает Советской власти и высказал опасения, что они могут выдать органам Советской власти участников повстанческой организации. ХРОСТОВСКИЙ предложил всех их убить. ХРОСТОВСКИЙ, РАДИОН Петр и я наметили к убийству следующих жителей деревни Долистово-Новое: 
1. ВАЛУШКО Казимира, 1920 года рождения, поляк, батрак, в 1940 году вступил в ряды ВЛКСМ, проводил политико-воспитальную работу среди молодежи в деревне, тесно был связан с секретарем комсомольской ячейки учителем ВОНЧЕ, прибывшим из Восточных областей.

2. ГЖЕГОРИЯ Леопольда, отчества не знаю, в возрасте 45-ти лет, поляк, бедняк, активист села.

3. ГЖЕГОРИЯ Антония - брат Леопольда, возраст 50 лет, поляк, бедняк, активист села.

4. ШИПУЛЬСКОГО Вацлава, около 23 лет, поляк, активно выступает за Советскую власть.

5. ЯНКОВСКОГО Станислава, 20 лет, поляк, бедняк, активист.

6. ЯНКОВСКОГО - Брат Станислава, иени не помню.

Перечисленные выше лица намеченные к убийству по дер. НовоДолистово ХРОСТОВСКИМ, были записаны к себе в записную книжку. Конкретных исполнителей террористических актов над указанными выше лицами в этот раз намечены не были. ХРОСТОВСКИЙ только сказал, чтобы РАДИОН и я организовали их убийство...”

«...В порядке выполнения намеченного плана убийства сельских активистов 8-го июня 1940 г. нами убит комсомолец из деревни НовоДолистово - ВАЛУШКО Казимир".

Касаясь подробностей убийства КУХАРСКИЙ показал: «Место где было совершено убийство ВАЛУШКО Казимира, сильно песчаное. ВАЛУШКО, как только выехал из деревни СтароеДолистово по направлению к дому, сразу же слез с велосипеда, шел пешком, велосипед вел в руках. Вслед за ним метрах примерно в 50 шел пешком я. Как только ВАЛУШКО прошел вербу растущую на дороге, из-за нее вышел стоявший там ХРОСТОВСКИЙ и в спину ВАЛУШКО Казимира нанес штыком удар. ВАЛУШКО сразу упал на землю и в это время ХРОСТОВСКИЙ нанес ему много уколов штыком в грудь. В это время подбежал и я...

Когда я и ХРОСТОВСКИЙ, ВАЛУШКО снесли с дороги в рожь и начали его обыскивать, он ВАЛУШКО начал тяжело стонать... После обыска ХРОСТОВСКИЙ нанес несколько ударов птыком по голове ВАЛУШКО Казимиру и, когда посладний не подавал признаков жизни, ХРОСТОВСКИЙ шттыком пробил ему виски. Убедившись, что ВАЛУШКО Казимир мертв, ХРОСТОВСКИЙ попрощавшись 
со мной ушел сказавши: «Теперь Вам будет спокойно, одного врага убили. Так потихонько одного за другим будем убивать всех».

(ХРОСТОВСКИЙ, якобы, в июле месяце 1940 года был ранен в обе ноги и находился на излечении в гор. Сувалках на территорию СССР не появлялся)

В своей преступной деятельности КУХАРСКИЙ в августе 1940 г. связался с Руководителем банды ПОЛУБИНСКИМ Антонием. Последний назначил его своим личным кур'ером для осуществления связи с комендантами пляцувак, действующих на территории Августовского и Моньковского районов. В вопросе о терроре ПОЛУБИНСКИЙ дал КУХАРСКОМУ следующую установку:

«Передать всем комендантам с которыми поддерживаю связь, чтобы они на месте, в каждом - конкретном случае лиц заподозренных в связях с органами НКВД и тех, которые могут выдать членов организации милиции или НКВД - убивали. Решение об убийстве должен выносить комендант пляцувки, с участием двух членов организации входяцих в состав пляцувки. Эта-же тройка должна подбирать людей и поручать им приводить решение тройки в исполнение»

(Из показаний арестованного КУХАРСКОГО от 18/1-41г.)

На предложение КУХАРСКОМУ рассказать о всех известных ему террористических актах над партийно-советским активом, последний показал:

«Примерно месяца полтора тому назад я ходил в дер. Ясиново к коменданту Ясиновской пляцувки ГАРОБУРДА Яну... В разговоре я спросил у ГАРОБУРДА, как у него дела, он мне ответил, что организация работает не плохо, понемножку убираем конфидентов НКВД. ГАРОБУРДА мне рассказал, что он вместе с братом ГАРОБУРДА Игнатием убили семъю, которая по его словам активно помогала органам НКВД. На мой вопрос - Кого? ГАРОБУРДА Ян сказал, что в дер. Домбовка, проживал ВОРОБЬЕВ Харитон Власович. Этот ВОРОБЬЕВ и его жена работая на мельнице, активно помогали НКВД. За это мы их и убили.

23-го декабря, когда я был на явке у ПОЛУБИНСКОГО, последний мне говорил, что по его поручению участник банды ГОДОМЕР Метык, уроженец деревни Домбово, Августовского района... убил активиста ЯБЛОНСКОГО Владислава. ПОЛУБИНСКИЙ также рассказал, что 
летом в дер. Копытково, Августовского района он лично убил члена ВКП(6) Уполномоченного комитате Заготовок СНК БССР, фамилию убитого он не назвал, только сказал, что у этого коммуниста был пистолет, который ПОЛУБИНСКИЙ забрал себе на память.

Тогда же 23-го декабря 1940 г. ПОЛУБИНСКИЙ говорил, что по его заданио был подготовлен террористический акт над жителем дер. Старое-Долистово, Моньковского района - ЕКА, имя его не знает. ЕКА должны были убить за то, что он являлся по словам ПОЛУБИНСКОГО агентом НКВД. Этот ЕКА был пойман и избит, но ему удалось бежать и когда он удирал, то исполнитель террористического акта - участник банды ПОЛУБИНСКИЙ по нем стрелял и якобы его ранил в ступнго ноги».

В вопросе о шпионской деятельности к/р повстанческой организации арестованный КУХАРСКИЙ показал, что ПОЛУБИНСКИЙ после того, как назначил его - КУХАРСКОГО личным связником, передал ему список комендантов пляцувок и руководителей пятерок Моньковского района и предложение - «озадачить всех комендантов пляцувок и руководителей пятерок, с которыми я должен был установить связь, собрать в ближайшее время сведения о расположении воинских частей в пограничных районах БССР, их численность, вооружение, род войск. Особенно обрагцал мое внимание ПОЛУБИНСКИЙ на сбор сведений о строительстве укрепленных точек в пограничной полосе, оборонных сооружений и строительстве военных городков"

(Из показаний арестованного КУХАРСКОГО от 18-го января 1941 г.) Следствие продолжается.

Агентурно-оперативную работу и следстви направляем на:

a) Установление и из'ятие всех участников $\mathrm{k} / \mathrm{p}$ повстанческой организации.

6) На обеспечение ликвидации банды ПОЛУБИНСКОГО в случае ее появления на территории ССР.

в) На выявление и из'ятие оружия.

НАЧАЛЬНИК УНКВД ПО БЕЛОСТОКСКОЙ ОБЛ. - ПОЛКОВНИК (podpis)

(М И С Ю Р В). 
31 января 1941 r.

№ $1 / 106^{c}$

г. Белосток. -

Oryginal, maszynopis.

$\mathrm{Na}$ górze dokumentu prostokątna pieczątka kancelaryjna: ${ }_{n} \mathrm{~W}_{\text {płynęłło, }} \mathrm{Nr}^{n}$ i niżcj ${ }_{n} 111.1941^{n}$

Z̈ródło: PAOSOG w Grodnie, zesp. 6195, spr. 1, t. 188, k. 132-143.

- Wielkic litery i podkreślenia oryginału.

'Slowa: „При вср6овке Яворского, Рахвальский” wpisane odręcznie.

' Dzień i nr wpisane odręcznie.

\section{Dokument 11}

1941 luty 28, Białystok, - Raport Zarzqdu Obwodowego NKWD obwodu białostockiego o okolicznościach zabójstwa naczelnika milicji rejonu łapskiego S. I. Zubaczewa i podjętych w zwiqzku $z$ t ym działaniach operacyjnych.

Совершенно секретно.

СЕКРЕТАРЮ БЕЛОСТОКСКОГО ОБЛАСТНОГО КОМИТЕТА КП(б)Б

товарищу К У ДР Я Е В У.:

З Д Е С $\mathrm{b}$.

\section{СПЕЦСООБЩЕНИЕ}

Утром 26-го февраля сего года в деревне Степулки Шиманы Лапского района, во время операции по из'ятию скрывающегося бандита МОЧЕДЛОВСКОГО А.И., последним, выстрелом из пистолета "Парабеллиум» убит начальник Лапского РОМ - Сержант Милиции ЗУБАЧЕВ Сергей Иванович, 1909 г. рождения, русский, уроженец из села Елисеевичи Брянского района Орловской области, член ВКП(б) с 1932 года, в органах PКМ с 10/XI-34 г. бывший начальник Поречьского РОМ. В Лапский район прибыл на работу 14-го февраля 1941 года. 
В указанную операцию задержаны и арестованы:

1. МОЧЕДЛОВСКИЙ Антоний Игнатьевич, 1920 г. рождения, поляк, уроженец из дер. Женцы Лапского района, участник террористической организации, находился на нелегальном положении.

2. МАЙКОВСКИЙ Казимир Теофилович, 1914 г. рождения, поляк, уроженеци житель из дер. Степулки-ІІІиманы, укрыватель МОЧЕДЛОВСКОГО, вел перестрелку с оперативной группой.

3. ВОЙНО Александр Казимирович, 1918 г. рождения, поляк, уроженец и житель дер. Красово Брянского района. Обнаружен в доме ЛЕСНЕВСКОГО - пособника и укрывателя бандита МОЧЕДЈОВСКОГО и ДУБКОВСКОГО.

4. ЛЕСНЕВСКИЙ Мечислав Александрович, 1912 г. рождения, поляк, уроженец и житель дер. Леснево-Медведь Лапского района, укрыватель бандитов МОЧЕДЛОВСКОГО и ДУБКОВСКОГО.

ГІредварительным расследованием на месте установлены следующие обстоятельства происшествия:

Начальник Лапского РО НКВД тов. КУДРЯВЦЕВ, располагая сведениями об активном пособничестве террористу БРУІІІЕВСКОМУ со стороны жителей деревни Брушево ГУЗОВОЙ и ГРАБОВСКОГО Люциана, принял решение задержать последних.

Из'ятие ГУЗОВОЙ и ГРАБОВСКОГО - КУДРЯВЦЕВ приказал провести Старшему Оперуполномоченному РО НКВД БАБАЕВУ и Оперуполномоченному ДЯГИЛЕВУ. Для этой цели ДЯГИЛЕВУ было предложено взять с собой 3-х сотрудников РОМ и выехать с ними 25-го февраля в м-ко Соколы. Об'единиться там с с группой БАБАЕВА и провести операцию. БАБАЕВУ же, находившемуся в это время во Вноровском сельсовете, Начальником РО НКВД было предложено выехать в Соколы и об'единиться с группой ДЯГИЛЕВА.

Как БАБАЕВ, а также и ДЯГИЛЕВ приказания не выполнили и от участия в операции уклонились. ДЯГИЛЕВ не выехал вовсе с группой милицейских работников, а БАБАЕВ будучи в отделении милиции в Соколах и зная, что оперативная группа милицейских работников во главе с ЗУБАЧЕВЫМ выходит ночью к месту операции, с ними не пошел, а самовольно выехал в Лапы.

ЗУБАЧЕВ-же и бывшие вместе с ним сотрудники РОМ Старший Оперуполномоченный МЯГКОВ, оперуполномоченный ДРАЧЕВ, пом. оперуполномоченный ГИЧАН, участковый уполномоченный ЗАВАДСКИЙ и участковые милиционеры СУІІРУНЮК и МАГРУК, не 
выполнив приказания отданного Начальником РО НКВД о задержании ГУЗОВОЙ и ГРАБОВСКОГО, вышли в д.Д. Леснево-Медведь и СтепулкиІІиманы с целью задержать скрывагоцегося ДУБКОВСКОГО Станислава, МОЧЕДЛОВСКОГО Антония и третьего, фамилия которого не была источнику известна.

ІІрибыв в дер. Леснево-Медведь, ЗУБАЧЕВ со своей оперативной группой задержали в доме ЛЕСНЕВСКОГО М.А. скрывающегося участника террористической организации «Батальон смерти ВОЙНО Александра Казимировича, 1918 г. рождения, уроженец из деревни Красово Брянского района и его укрывателя хозяина дома ЛЕСНЕВСКОГО Мечислава Александровича, 1912 г. рождения. Захватив с собой задержанных оперативная группа перешла в деревно Степулки-Шиманы и оцепила дом МАЙКОВСКОГО К.Т.

Из состава оперативной группы в дом для осмотра вошли: ЗУБАЧЕВ, МЯГКОВ и СУПРУНЮК. Осмотром жилых помещений никого не обнаружили, после чего ЗУБАЧЕВ поднялся по лестнице на чердак и тотчас начал интенсивную перестрелку с неизвестным лицом, укрывшимся на чердаке. IІосле нескольких выстрелов, ЗУБАЧЕВ будучи смертельно ранен упал с чердака на поднимавшегося по лестнице СУПРУНЮКА и им был снесен во двор. Тотчас, как СУПРУНЮК и МЯГКОВ вынесли раненного ЗУБАЧЕВА из дома, в сенях разорвалась брошенная с чердака граната, а находившийся на чердаке неизвестное лицо начал обстрел сотрудников находившихся в оцеплении дома. Оперативная группа отвечала. В течение двух часов перестрелки бандитами было брошено несколько гранат не причинивших вреда.

В 12 часу дня к месту перестрелки прибыл Зам. Начальника 3 Отдела УНКВД тов. ЮРИН и спустя непродолжительное время бандит МОЧАДЛОВСКИЙ и его соучастник МАЙКОВСКИЙ, находившиеся в доме, израсходовав почти все патроны, подожгли изнутри дом и пытались бежать, но были обстреляны, ранены и пойманы. В сенях сгоревшего дома были обнаружены пистолет «Парабеллум» без патрон, польская винтовка, заряжаная на два патрона.

Допросом тяжело раненого МОЧЕДЛОВСКОГО получены показания, что он является участником контрреволюционной организации «Батальон смерти", завербован в апреле 1940 года МОЧАДЛОВСКИМ Антоном Александровичем, бежавшим в Германию' в мае 1940 r.

Из числа участников «Батальона смерти» МОЧЕДЛОВСКИЙ назвал 10 человек, в большинстве проживагоцих на нелегальном положении 
и, уездным комендантом организации назвал РОЖКОВСКОГО Феликса, находящегося на нелегальном положении и его заместителя (фамилию не назвал), работающего в кооперативе в дер. Коробы. Кроме того, показывая о РОЖКОВСКОМ, МОЧЕДЛОВСКИЙ заявИл, что РОЖКОВСКИЙ является физическим исполнителем террористического акта над БУСЯК Юльяном, убитым по подозрению в работе с НКВД.

Называя известных ему участников организации МОЧЕДЛОВСКИЙ показал, что братья РОСКОСТЯКИ (скрываются) убили жителя дер. Перки по имени Валерия (фамилию, мотивы убийства, обстоятельства и время не назвал). Из за сильной слабости ввиду тяжелого ранения МОЧЕДЛОВСКИЙ показания давал с трудом и в 23 часа 40 минут 26-го февраля 1941 года умер.

Показанное МОЧЕДЛОВСКИМ используем в следствии по делу задержанных в операцию и принимаем меры к оперативной реализации в отношении других лиц названных в показаниях.

Помимо самоустранения ДЯГИЛЕВА и БАБАЕВА от руководства операцией, главной причиной плохого исхода ее явилось грубое нарушение аппаратом Управления милиции и РОМ непосредственно в Лапах, моих неоднократных письменных и устных указаний о непременном согласовании всех операций по из'ятиюо скрывающихся преступников.

В данном случае УРКМ, имея с 18-го февраля 1941 года в своем распоряжении данные c/o. «ПАВЛЮКОВ" о местонахождении скрывающегося вооруженного ДУБНОВСКОГО С. А. не поставило в известность меня о наличии такого сигнала, а переслали донесение в Лапское РОМ, при чем с абсолютно неопределенным указанием. В препроводительной к донесению начальнику РОМ было предложено «проверить». Как и что проверить не рекомендовано. Естественно, что ЗУБАЧЕВ имея только такое указание и не согласовав мероприятий по проверке с РО НКВД, проявил ненужную самостоятельность, повлекшую за собой жертву.

Мною запрошено указание $^{d}$ зам наркома Внутренних дел Бел. Особоуполномоченному НКВД БССР и Особой Инспекции УРКМ НКВД БССР о высылке сотрудников для полного расследования происшествия на месте ${ }^{e}$ и выявления виновников.

НАЧАЛЬНИК УПРАВЛЕНИЯ НКВД БЕЛОСТОКСКОЙ ОБЛАСТИ -

(МИСЮРЕВ) (podpis) 
27 февраля 1941 г.

№ $\underline{3 / 1031}$

г. Белосток.

Отпечат. 4 экз.

1-й и 2-й экз. - адресатам

3-й и 4-й " в делах 3 Отдела.

Oryginal, maszynopis.

Na górze dokumentu z lewej strony ukosem adnotacja: „Zapoznać Sekretarzy Obkomu” i niżej podpisy Popowa, Anisimowa i Sawałowa oraz data 2/111/41.

Źródło: PAOSOG w Grodnie, zesp. 6195, spr. 1, t. 189, k. 12-16.

a Podkreślenia i wielkie litery oryginału.

"Skreślone słowa: „I lрошу дать" і wpisano „Мною запрошено”.

' Po tym słowie wpisano odręcznie: „зам иаркома Внутренних дел Бел."

"Po tym slowie dopisano odręcznie: „и выя вления виновииков".

' Dzień i nr wpisane odręcznie.

' Chodzi o okupowane przez Niemców ziemie polskie, w tym wypadku o Generalne Gubernatorstwo.

\section{Dokument 12}

1941 luty 28, Bialystok, - Raport specjalny Zarzq̨u Obwodowego NKWD obwodu białostockiego o stanie rozpracowywania członków POW w obwodzie.

Совершенно секретно.

Подлежит возврату

СЕКРЕТАРЮ БЕЛОСТОКСКОГО ОБЛАСТНОГО КОМИТЕТА КП(б)Б

товарищу К УДР Я Е В У.

3 десь . 


\section{II E I. I С О О Б ІЦ Е Н И Е \\ о состоянии учета и разработки членов «IIOB» по \\ Белостокской области.}

После прихода к власти ІІилсудского в 1927 году, в гор. Белостоке, как равно и по всей ІІольше был создан окружной союз бывших участников "IIOB", а в пределах воеводства были созданы филиалы. Такие филиалы «ПОВ» существовали в 9-ти уездах бывшего Белостокского воеводства.

В городе Белостоке, наряду с окружным и уездными союзами существовал городской союз “ГІОВ». ГУутем добытых нами архивных материалов - личных дел членов "ПОВ» и других документов установлено, что Белостокский окружной союз «ПОВ» в составе 9-ти уездных филиалов имел 1951 члена, в том числе:

1. Белостокский

$$
\text { - } 154 \text { члена }
$$

2. Августовский

$$
-253 \text { “ }
$$

3. Волковыский

$$
\text { - } 28
$$

4. В-Мазовецкий

$$
-190 \text { " }
$$

5. Граевский

-159 "

6. Ломженский

$-350$

7. Соколковский

$-29$

8. Гродненский

$-183$

Остальные 605 человек состояли в уездных филиалах «ПОВ» по

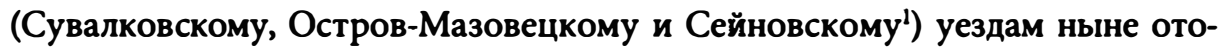
шедшим к Германии.

На 5-е февраля 1941 года по области выявлено и взято на оперативный учет 282 человека членов «ПОВ». Кроме того установлено 67 человек сбежавших на территорию Генерал Губернаторства и 61 человек ранее арестованных как участники контрреволюционных повстанческих организаций.

Из числа взятых нами на учет и в разработку бывших членов «IIOB» на 19 человек заведены дела-формуляры, из которых наиболее характерными являются:

\section{ПО ГОРОДУ БЕЛОСТОКУ:}

1. На ЯГИНТОВИЧ Яна Адамовича, 1888 года рождения, уроженец и житель города Белостока, по национальности поляк, женат, гражданин СССР, работает в «Белгоспроекте» инженером. ІІроживает по ул. Белорусской дом № 11 кв. 2. 
ЯГИНТОВИЧ является активным членом «ПОВ», занимал пост Председателя Ревизионной комиссии окружной организации. В период функционирования "Торгсинов" нелегально пересылал денежную валюту БЕЖМАН Клавдии Дмитриевне, проживающей в гор. Новосибирске. Последняя отделением ДТО НКВД Томской железной дороги разрабатывается по подозрению в пппионаже.

\section{ПО ЦЕХАНОВЕЦКОМУ РАЙОНУ.}

1. РОДЗИШЕВСКИЙ Антон, 1898 г. рождения, уроженец и житель дер. Винно-Выпихи, являлся членом "ПОВ" с 1916 до 1918 года под кличкой «ВОЛОДЫЕВСКИЙ». РОДЗИШЕВСКИЙ настроен антисоветски. В разговоре с нашим агентом говорил:

... «Советской власти на территории Западной Белоруссии скоро не будет. Германия победит Англию и поможет полякам освободить территорию от болыпевиков».

2. ДОМБРОВСКИЙ Юльян Антонович, 1904 г. рождения, уроженец дер. Тымянки-Скляжи, по национальности поляк, проживает в дер. Богуты. ДОМБРОВСКИЙ являлся членом «ПОВ" до 1939 года. Работал помощником Секретаря гмины, состоял членом партии "ОЗН". Настроен антисоветски, поддерживает связь с кулаками и ксендзом.

\section{ПО БЕЛЬСКОМУ РАЙОНУ.}

1. ЗАРЕМБА Юзеф Андреевич, 1896 г. рождения, уроженец и житель дер. Выгоново, поляк, из крестьян - середняков. С 1917 по 1918 года состоял членом «ПОВ", под кличкой "ЛЕВ" выполнял должность коменданта. Доброволец польской армии. В 1920 году принимал активное участие в борьбе против Красной армии.

2. КУЛЕША Николай Юльянович, 1899 г. рождения, уроженец дер. Кореневки Семятичского района Брестской области, по национальности поляк, проживает в дер. Выгоново Бельского района. КУЛЕША с 1917 года являлся членом "ПОВ». В 1918 году выезжал на жительство в Америку, там состоял в легионах генерала ГАЛЕРА.

3. ЗАВАДСКИЙ Станислав Францишкович, 1896 г. рождения, уроженец и житель дер. Завады, по национальности поляк, кулак, член «ПОВ» с 1920 
года. Являлся добровольцем бывшей польской армии и принимал активное участие в боях против Красной армии. С момента установления Советской власти на территории Западной Белоруссии ЗАВАДСКИЙ распространяет разного рода контрреволюционные измышления о Красной армии заявляя:

... «В Красную армию итти служить не нужно, она нам ничего хорошего не дала. Я сам, хотя и являюсь военнообязанным и мне нужно тоже итти вставать на военный учет, но в Красной армии служить не буду и, сделаю все, чтобы только удрать в Германию».

ЗАВАДСКИЙ имеет близкие связи с жителями той же деревни ЗАВАДСКИМ Эдвардом Карловичем, БОЛЕСТА Францем Ивановичем и другими, которые разрабатываются по подозрению в повстанческой деятельности.

Нами намечены и проводятся следующие мероприятия:

1. Весь добытый архивный учет на членов «ПОВ», с целью оперативного использования переводится с польского языка и направляются в РО НКВД по месту нахождения членов «ПОВ» для установки последних и взятия в агентурную разработку.

2. Всем начальникам Горрайотделов и райотделений НКВД дано указание об активизации агентурной разработки членов "ПОВ» (для чего систематизировать весь имеющийся в Горрайотделах и райотделениях НКВД учет по пеовякам).

ІІересмотреть всіо действующую сеть, работающую по освещению и разработке членов "ПОВ», и всю неработоспособную и подозрительную по двурушничеству агентуру отсеять и подобрать более работоспособную, могущую проникать в контрреволюционную среду пеовяков, для вскрытия в этой среде имеющихся контрреволюционных формирований. -

НАЧ УНКВД ПО БЕЛОСТОКСКОЙ ОБЛ.

(podpis) (МИСЮРЕВ)

28 февраля 1941 г.

№

г. Белосток.

Отпечатано 4 экз.

1-й экз. - Наркомвнудел БССР

2-й “ Секрет. Обкома КІІ(6)Б

3 и 4-й экз. в делах 3 Отдела. 
Исп. Тимофеев.

Oryginal, maszynopis.

'̇ródło: PAOSOG w Grodnic, zesp. 6195, spr. 1, t. 188, k. 235-239.

- Podkreslenia i wielkie litery oryginału.

' Słowa: „Подлежит возврату” wpisane odręcznie i dwukrotnie podkreślone.

' Dzien wpisany odręcznie. Brak numeru.

' Powiat sejneński zostal w 1925 r. zlikwidowany, a jego tereny włączone do pow. suwalskiego.

\title{
Dokument 13
}

1941 luty, Bialystok, - Raport specjalny Zarzq̨du Obwodowego NKWD obwodu białostockiego o rozpracowywanej $w$ rejonie bielskim sprawie agenturalno-śledczej „Olszewiacy”.

\section{COBEPШEHHO CEKPETHO. ${ }^{a}$}

\author{
НАРОДНОМУ КОМИССАРУ ВНУТРЕННИХ ДЕЛ БССР \\ КОМИССАРУ ГОСУДАРСТВЕННОЙ БЕЗОПАСНОСТИ 3-ГО РАНГА
}

Товаришу Л. ЦА Н А В А.

гор. Минск.

\section{С П ЦС О О Б ЦЕ НИЕ.}

В августе месяце 1940 года, поступившими агентурными материалами по заведенной разработки "ОЛЬШЕВЦЫ» на территории Бельского района, вскрыта контрреволюционная повстанческая организация, являющаяся филиалом «Союза вооруженной борьбы".

Организация была создана в начале 1940 года - активной польской националисткой - учительницей дер. Ольшево, АДАМЧУК Брониславой 
Константиновной, (полька, 1905 года рождения), из числа быв. членов контрреволюционной партии «Народовцев», военнослужащих быв. польской армии, кулаков и другого контрревольоционного элемента. Всего в составе к.-р. повстанческой организации насчитывается до 40 человек.

Организация ставит перед собой задачу - подготовить из числа польских националистов и лиц контрреволюционно-настроенных - повстанческие кадры, для вооруженной борьбы с Советской Властью.

По контрреволюционной деятельности АДАМЧУК Бронислава была связана с Варшавским повстанческим центром, через представителя этого центра офицера быв. польской армии, в прошлом коменданта к.-р. фашистской организации “Союз Стрельцов» и «Кракусов" - ПЕТРОВСКОГО Яна Антоновича, а так же через специально выделенного связного от к.-р. организации - ЯЗВИНСКОГО Антона Ивановича, который неоднократно нелегально переходил через гос. Границу в гор. Варшаву с заданием от АДАМЧУК и приносил директивные указания по к.-р. деятельности организации.

В ноябре месяце 1940 года ПЕТРОВСКИЙ Ян Антонович, Варшавским повстанческим центром был направлен в качестве коменданта повстанческих организаций по Бельскому округу, при нелегальном переходе госграницы был задержан, в настоящее время содержится в Брестской тюрьме. (Нами направлен оперативный работник в г. Брест, для этапирования IIETРОВСКОГО в г. Белосток, на предмет ведения следствия по всрытию к.-р. деятельности организации.)

Одновременно с этим АДАМЧУК Бронислава поддерживала организационную связь, через ГЯРО Станиславу (арестована), с членами окружного штаба контрреволюционной повстанческой организации “СВБ» в гор. Белостоке.

Свое руководство контрреволюционной повстанческой организацией АДАМЧУК Бронислава осуществляет через назначенных ей комендантов контрреволюционных повстанческих групп, созданных в следующих населенных пунктах:

1. В дер. Ольшево - комендантом к.-р. группы является ОЛЫШЕВСКИЙ Станислав Павлович, 1906 года рождения, кулак, капрал быв. польармии.

2. В дер. Бодаки - комендантом к.-р. группы является МАКСИМОВИЧ Людвиг, 35 лет, быв. сотрудник польской полиции

3. В дер. Гаврилки - комендантом к.-р. группы является ЖИІІНЕВСКИЙ Иван Осипович, 30 лет, состоял членом к.-р. организации «Кракусов». 
4. В дер. Труски - комендантом к.-р. группы является СКШИПОВСКИЙ Иван, 38 лет, сержант быв. польской армии, состоял членом к.-р. организации «Кракусов".

5. В дер. Бодачки - комендантом к.-р. группы является ШЕМЧУК Станислав Клементьевич, 1908 года рождения, быв. руководитель к.-р. организации «Народовцы» в дер. Бодачки.

6. В дер. Скшипки - комендантом к.-р. повстанческой группы является СИКМАЦКИЙ Павел Поликарпович, 40 лет, поляк.

Антисоветская деятельность участниками контрревоююционной повстанческой организации проводится в направлении:

a) Расширения состава к.-p. повстанческой организации, за счет лиц враждебно настроенных к Советской Власти, причем вербовка участников в организацию разрешена только комендантам к.-р. повстанческих групп.

6) Подготовки к совершению террористических актов над партийносоветским активом.

в) Сбор шпионских сведений о расположении воинских частей и их вооружении, для чего участниками контр.-революционной организации был направлен на работу в столовую воинской части, находящуюся в дер. Андриянки - ВЕРТИНСКИЙ Валерьян Антонович (арестован).

г) Проведении злобной антисоветской агитации направленной против хозяйственно-политических мероприятий партии и правительства.

Для обсуждения вопросов практической контрреволіоционной деятельности организации, участниками систематически проводятся нелегальные сборища, которые происходят в квартире ОЛЬШЕВСКОГО Станислава.

Завербованный нами из числа участников организации в качестве с/о Вайдаковский Ст. Ф.', под кличкой "СТРЕЛА" при вербовке сообщил, что в к.-р. повстанческую организацию его завербовал ОЛЬШЕВСКИЙ Станислав, последний ему предлагал совершить террористический акт над милиционером дер. Ботьки КУПЕР ШИПКО, для чего в последнее время дал револьвер при вручении которого заявил:

«Передаю револьвер и надеюось как на себя, что это оружие нам скоро пригодится».

В поступивших последующих агентурных донесениях источник "СТРЕЛА" сообцил, что в происходившей беседе с активным участником к.-р. повстанческой организации ВЕРТИНСКИМ Вацлавом Антоновичем, последний заявил, что он с КАМИНСКИМ Казимиром (участник к.-p. 
организации) имел намерения во время выборов депутатов в Верховный Совет СССР и БССР бросить гранату в избирательный участок но так как в это время там неоказалось ответственных партийно-советских работников, этот террористический акт совершен не был.

Анологичные намерения по совершению диверсионно-террористического акта, высказывал нашему источнику “СТРЕЛА» другой участник повстанческой организации - ОІЫЫЕВСКИЙ Владислав Адамович, заявляя: "что если бы трактора стояли ближе к нашей деревне, я бы бросил в них имеюциеся у меня две бомбы».

Агентурные материалы источника "СТРЕЛА», о наличии значительного количества оружия, гранат, винтовок, револьверов, у участников организации, перекрываются агдонесениями источника "БЫСТРЫЙ».

В целях быстрейшей ликвидации к.-p. повстанческой организации, дальнейшие агентурно-оперативные и следственные мероприятия по агентурному делу “Ольшевцы» направляем на установление и арест всех участников и руководящего состава к.-р. повстанческой организации, выявления каналов, по которым осуществляется связь с Варшавским повстанческим центром, а так же и с членами Окружного штаба "СВБ», обнаружения и из'ятия имеющегося оружия у участников организации, для чего:

а) Через ОБЛОНО в гор. Белосток вызываем АДАМЧУК Брониславу, где она будет негласно снята и арестована.

6) Этапируем из Брестской тюрьмы в гор. Белосток IIETРОВСКОГО, который будет допрошен по вопросам руководства Варшавским повстанческим центром, повстанческими организациями существующими на территории Западный областей БССР.

в) Подготовляем материалы на вербовку в качестве агентов внутренников Зелинского Степана Ивановича и Язвинского Вацгава. ${ }^{d}$

В помоць для проведения агентурно-оперативных мероприятий по подготовке к ликвидации к.-р. повстанческой организации, командируем в Бельский РО НКВД - опытного оперативного сотрудника УНКВД.

О результатах донесу дополнительно.

ІІРИЛОЖЕНИЕ: Список лиц проходяцих по разработке. ${ }^{1}$

НАЧАЛЬНИК УІІРАВЛЕНИЯ НКВД БЕЛОСТОК. ОБЛ.

П О л К О В н и $\mathrm{K}$

( М И Ю Р В В ) 
" " февраля 1941 г.

№

г. Белосток.

Kopia, beı podpisu.

Źródło: PAOSOG w Grodnie, zesp. 6195, spr. 1, t. 188, k. 240-244.

\footnotetext{
a Wielkie litery i podkreślenia oryginału.

b Słowa: „систематически" wpisano odręcznie w miejsce skreślonego słowa „неоднократно".

c Nazwisko: „Вайдаковский Ст. Ф.” Wpisano odręcznie w pozostawione w maszynopisie miejsce.

¿Nazwiska: „Зелинского Степана Ивановича и Язвинского Вацлава” wpisane odręcznie w pozostawione w maszynopisie miejsce.

"Słowa: „донесу дополнительно" wpisano odręcznie w miejsce skreślonego słowa "сообщим".

' W teczce brak wymienionego załącznika.
}

\section{Dokument 14}

1941 marzec 13, Białystok, - Raport specjalny Zarzq̨u Obwodowego NKGB obwodu białostockiego o stanie pracy operacyjnej wśród inteligencji w $1940 \mathrm{r}$.

Сов. Секретно

СЕКРЕТАРЮ БЕЛОСТОКСКОГО ОБКОМА КП(б)БЕЛОРУССИИ

тов. К УД Р Я Е В У'

СПЕЦ-СООБЩЕНИЕ

О состоянии агентурно оперативной работе по интеллигенции

В итоге проведенной агентурно-следственной работы за истекший 1940 год установлено, что бывшим польским правительством состав интиллигенции комплектовался за счет польского контрреволюционно-националистического элемента.

Учительский состав, как основная часть интеллигенции офицеры резерва бывшей польской армии, принадлежали к различным национали- 
стическим контрревопоционным формированиям и фашистским партиям: - «ОЗН", «ББВР», «Народовцы», и т.д. - принимал активное участие в проведении всех мероприятий бывшего польского правительства, о чем в 1939 году, 23 мая, начальник отдела госбезопасности бывшего Белостокского воеводства - КЕЛЛЕР Адам, на с'езде старост заявил: -

«Мы ставим вопрос ассимиляции без дискуссии. Ассимиляции не только государственной, но и национальной, т.е. колонизацию.

Инструментами ассимиляции должны быть: - школа, общественные организации молодежи... До сих пор школа удовлетворительно использует свои обязанности. Следует, однако, еце больше втянуть в обцественную жизнь учителей, дабы не оставляли без своего попечения молодежь, которая кончает школу и вербовали бы ее в общественные организации»...

(Из архивных материалов)

О идеологическом направлении учительского персонала при бывшем польском правительстве свидетельствует то, что на протяжении ряда лет в должности начальника просвеццения Белостокского воеводства был БУДЗАНОВСКИЙ, один из организаторов и активных деятелей комитета «Борьбы с коммунизмом».

Восстановление Советской власти на территории Западных областей Белоруссии, контрреволюционно-националистический элемент, среди польской интеллигенции воспринял враждебно и начал формировать вокруг себя контрреволоционную молодежь под лозунгом борьбы против Советской власти, за восстановление бывшего польского государства.

В числе 177 человек, - националистической польской интеллигенции, арестованных за контрреволюционную деятельность - 150 человек - учителя и учащаяся молодежь.

Наряду с этим также установлено, что в вскрытых на территории Белостокской области крупных контрреволюционных повстанческих организациях: “Союз вооруженной борьбы», «Батальон смерти», насчитывающие в своих рядах свыше пяти тысяч человек членов, участники таковых из учителей занимали руководяцее положение, как например: -

Членом окружного Белостокского штаба контрреволюционной повстанческой организации была БОРКОВСКАЯ Софья-Янина Владиславовна, 1904 года рождения, уроженка г. Друскеник, бывшая учительница физкультуры жел.дор. НСIII г. Белостока (арестована 26/II-41 г.).

Заместителем руководителя контрреволюционной повстанческой организации «Батальон смерти», бывший учитель начальной школы дер. 
Тыборы-Ушинска, Чижевского района - ЗАХАРЖЕВСКИЙ Юзеф, поручик резерва бывшей польской армии (Сбежал за границу в мае 1940 года).

Районными комендантами этой же контрреволюционной организации по Цехановецкому району был ЖИТИНСКИЙ Хенрик, учитель НСШ дер. Кргоково, а в Замбровском районе - ПЕРКОВСКИЙ Антоний, сержант бывшей польской армии, учитель начальной школы дер. Калиново Старое.

В Граевском, Лапском, Августовском районах учителя школ лично сами создали повстанческие организации, вовлекая в таковые националистическую молодежь окружаюгцих деревень.

Арестованный ПЕРКОВСКИЙ Станислав Александрович, директор начальной школы д. Калиново-Чесново, Замбровского района показал, что в июне 1940 года он создал террористическо-повстанческую организацию и своим заместителм назначил учителя этой же школы ПАВЛОВСКОГО Эдмунда Юзефовича, 1910 года рождения. Следствием установлено 27 участников этой организации которые об'единялись пятерками и ставили своей задачей проведение террористических актов над местным активом. Следствие продолжается.

В январе месяце 1940 года учителем начальной школы дер. Сойчин Зоровой, Рудовского сельсовета, Граевского района БАРТЧИКОВСКИМ Яном была создана контрреволюционная повстанческая организация “Звензюк боювки младых", которой он и руководил по день ареста, т.е. 3/X-1940 года.

По данному вопросу обвиняемый БАР'ГЧИКОВСКИЙ показал, что в начале января месяца 1940 года, после занятий проводившихся по линии Граевского РайОНО, он направился в столовую. По дороге встретил ОСИПОВСКОГО Юзефа, бывшего поручика резерва 42го Белостокского пехотного полка, и совместно направились в столовую обедать. ОСИПОВСКИЙ Юзеф знал БОРТЧИКОВСКОГО как бывшего инструктора организации "Млода польской» и не стесняясь начал говорить, что он ОСИПОВСКИЙ проживает на нелегальном положении в городе Белостоке и проводит работу на территории: - Высоко-Мозовецкого, Ломжинского, Щучинского и Августовского уездов, по созданию контрреволюционных повстанческих организаций, направленных против Советской власти. Эта организация именуется “Звензок боювка млодых» и предложил БАРТЧИКОВСКОМУ чтобы он тоже начал работать по созданию контрреволюционной повстанческой организации на территории Щучинского уезда и быть его заместителем по созданию организации. Предложение ОСИПОВСКОГО он принял, после чего последний дал ему псевдоним 
«Накеш». Выйдя из столовой ОСИПОВСКИЙ дал БАРТЧИКОВСКОМУ подписать готовый бланк присяги.

При вербовке участников в контрреволюционную повстанческую организацию, ОСИПОВСКИЙ дал установку БАРТЧИКОВСКОМУ подбирать гминных комендантов из энергичных и проверенных поляков, офицеров и подофицеров бывшей польской армии и давать им поручения, что бы каждый из них создал в деревнях к/р повстанческие группы численностыо не более 5 человек, а также через них изыскивать на местах оружие.

В Августовском районе из числа 25 человек арестованных учителей: - двое были членами штаба контрреволюционной повстанческой организации, четверо руководителями уездного комитета «Нацилнальной обороны», шестеро активных участников повстанческой организации, десять бывших руководителей фашистских партий и организаций.

В Снядовском районе из Девяти арестованных учителей, семь активных руководителей контрреволюционной повстанческой организации.

О значительной засоренности учительского персонала школ в области контрреволюционным националистическим элементом $\mathrm{K}$ настояцему времени характуризуют данные произведенной проверки их по районам.

Из 187 человек учителей состоящих на учете Районных отделений НКВД: -

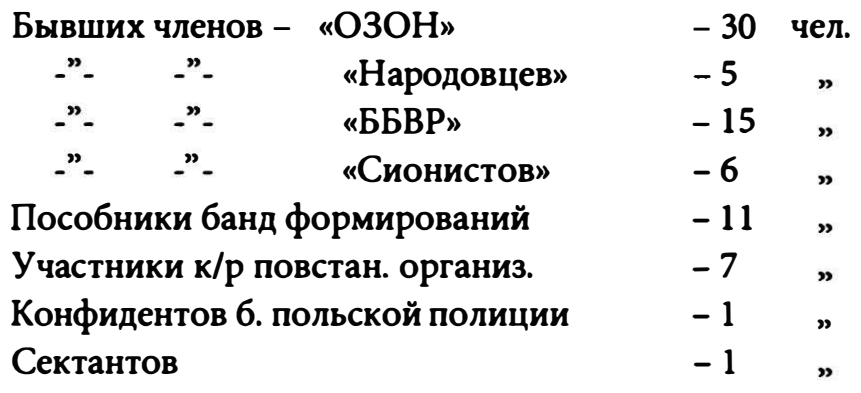

Бывших людей антисоветски нас-

троенных

$121 \quad$

Примером засоренности учительского состава отдельных школ является Озерская белорусская НСШ, где в числе 25 чел. учителей: -

Бывших членов "ОЗОН", они же состояли

в комитете борьбы с коммунизмом - 6 человек

Быв. псоломщик

Дочь служителя культа

Жен офицеров 6. польской армии

$-1 \quad-"$

$-1-n-$

-3 -" 
Из 187 человек состоявпих на учете учителей проходят по разработкам 17 человек, по делам формулярам 50 человек и по учетным делам 120 человек.

По агентурному делу «Мазуры» Белостокского Горотдела УНКВД контрреволюционной повстанческой организации “Союз вооруженной борьбы» проходят: -

1) ГУБОР Владимир Гаврилович 1902 года рождения, директор Н. Амисакуловской НСШ, арестован 6/III-41 г. дал показание о том, что он в июле месяце 1940 года завербован бывшим заместителем уездного комитета ГРИГО Станиславом «Михаил» и назначен комендантом гмины.

2) ГРОМАН Леон 1919 года рождения, учитель школы Крулевой Мост, Заблудовского р-на (подлежит аресту), является участником повстанческой $\mathrm{\kappa} / \mathrm{p}$ организации "СВБ». У себя имеет радиопередатчик, знает о наличии $\mathrm{k} / \mathrm{p}$ организации среди белоруссов в 6. гмине Городок, Заблудовского района.

3) ОСТАШЕВСКИЙ бывший учитель школы в Супрасле, в данное время в Летниковской пाколе, проходит по аг. материалам как участник контрреволюционно-диверсионной организации, созданной в ноябре месяце 1939 года в Супрасле, организация влилась в "СВБ".

По агентурному делу "Личность патриота", Бельского РО НКВД, проходят 10 человек учителей НСШ м-ко Орля, из них членов “ОЗОН" -2 человека, членов “ББВР» - 2 чел., один информатор бывшей польской полиции, одна жена офицера 6. польской армии, и 4 человека выходцев из соц. чуждой среды.

Возглавляет эту группу работающий в данное время директором НСШ - ВРУБЛЕВСКИЙ Феодосий Антонович, 1895 г. рождения, поляк, бывший руководитель к-р фашистской организации “ОЗОН" в м-ко Орля. За свою активную деятельность в “ОЗОН» имеет от 6 . польского правительства награды-медали.

Участники контрреволюционной организации проводят в квартире ВРУБЛЕВСКОГО нелегальные сборища. Практическая деятельность их сводится к обработке и вовлечению в к-р организацию из числа местных жителей лиц враждебно настроенных против Советской власти, под контрреволюционным позунгом «Восстановление бывшего польского государства».

Разработку ведут два агента “Жернов» и «Щука».

Характерным для лиц проходящих по формулярному учету в Бельском РО НКВД, по своей контрреволюционной деятельности является разрабатываемый по делу формуляр №-941- 
ЯРОНСКИЙ Тадеуш Владиславович 1896 г. рождения, поляк, при 6. польском правительстве был директором школы в г. Бельск, активный участник "ОЗОН", проводил в школе работу полонизацию белорусской и еврейской молодежи, за что имеет крест заслуги. В данное время работает учителем школы г. Белостока и проводит a/c пропаганду среди своих близких знакомых».

10/VII-1940 года ЯРОНСКИЙ в беседе агенту «Петрову» заявил: -

"Ничего, дождемся еще своего времени, хотя теперь наших мучагт, отнимают и убивают все что нам дорого как патриотам. Надо теперь быть глухим, слепым и мало говорить потому, что кругом коммунистический шпионаж. Наше дело поддерживать своих и знать кого забирают и куда вывозят.»

Августовским РО НКВД в числе 25 человек учителей разрабатываемых по делам формулярам 6 человек проходят как укрыватели и сообщники банды ПОЛУБИНСКОГО, как например: -

По показаниям арестованного КУКЛИНСКОГО, братья ЛИНКОВСКИЕ выходцы из кулаков неоднократно представляли убежище руководителю банды ПОЛУБИНСКОГО -

«Назначенные мною два брата ЛИНКОВСКИЕ Апполинарий и Станислав, по своим убеждениям являются ярыми польскими националистами... В их доме систематически скрывались руководители банды СТАНКЕВИЧ, ПОЛУБИНСКИЙ и др. ... Я сам лично два раза присутствовал на пьянках устраиваемых ими в доме ЛИНКОВСКИХ...

ЛИНКОВСКИЙ Апполинарий работает учителем в начальной школе в дер. Дренство, а его брат ЛИНКОВСКИЙ Станислав в дер. Тайно, Августовского р-на.

В пособничестве и связях с бандой разрабатывается учительница начальной школы дер. Езерки, Устянского сельсовета ЖЕПЕЦКАЯ Мария Эдвардовна.

С/о «Гаврилов» в донесении сообщает: -

«...Бандит ЯГЛОВСКИЙ 1-го декбря 1940 года, будучи в доме источника рассказал, что в дер. Езерки проживает учительница, полька, которая предлагала ЯГЛОВСКОМУ сообщить бандиту ИГНАТУ чтобы он убил РОДЗИЛОВА Яна, 32-х лет, жителя дер. Езерки за то, что он якобы помогает НКВД и выдает бандитов, а также за то, что он хотел проводить сотрудников НКВДдо Червоного Багно, где скрываются бандиты.» 
Также установлено, что учительница ЖЕПЕЦКАЯ распространяет контрреволюционные слухи о неизбежности гибели Советской власти и установления капиталистического государства.

Муж ЖЕПЕЦКОЙ бывший лесник, в кругу своих знакомых заявляет: «За то время, которое я вынулкден быть без работы мне уплатит будущее правительство Польши.»

Разрабатываемые Августовским РО НКВД 4 учителя, как участники контрреволюционной повстанческой организации, из них 2 по агентурно следственному делу “Хвосты» - ДРИЛЯ Станислав и ГРАЖЕВИЧ Владислав.

Поощрали к/p деятельность своих детей, зная, что они занимаются шпионской деятельностью в пользу Германии.

Арестованный ДРИЛЬ Владимир Станиславович, 13/XII-1940 года показал: -

"О том, что я занимаюсь шпионажем знает мой отец и мать, так как дней через пять после того, как я был завербован ЧАРНЕЦКИМ Чеславом для шпионской работы - я рассказал матери в присутствии своего отца и братьев и указал о полученном задании - воровать у командиров РККА документы и направлять их через ЧЕРНЕЦКОГО за границу в Германию.»

Сын учителя ГРАЖЕВИЧ - ГРАЖЕВИЧ Генрих также арестован 86 погранотрядом НКВД, как агент германской разведки.

Лично ДРИЛЬ Станислав в кругу своих знакомых проводит к-р пропаганду утверждая, что «Скоро будет восстановлено бывшее польское государство", о чем РО НКВД сделал заявление гр-н СЕВОСТЬЯНОВИЧ Казимир: -

"ДРИЛЬ - учитель НСШ воспитывает молодежь в духе национализма и ненависти к Советской власти, заявляя: «Советская власть долго существовать не будет. Англия скоро победит Германию и освободит нас. Скоро здесь будет Полыпа.»

В Свислочском РО НКВД, по агентурному делу «Блок» проходят как активные руководители контрреволюционной повстанческой организации учителя НСШ дер. Рожки.

РЖЕВСКИЙ Леонард Иванович 1901 года рождения, подозревался в прошлом в связях польской полиции, в данное время работает 
директором НСШ. РЖЕВСКИЙ Л.И. давая указания членам организации о практической деятельности заявляет: -

«Надо пока тихо сидеть, меньше говорить, а больше делать, я вот именно так и поступаю и поэтому сижу директором НCIII, мне верят, а я свое дело делаю. ІІоляки люди культурные, а большевики - это дичь разве дикари побеждали когда культурный народ.»

Наряду с непосредственной контрреволюционной деятельностью учительского персонала в повстанческих и других к-р формированиях установлены факты, что отдельные из них в настояцее время пытаются восстановить существовавшие при бывшем польском правительстве националистические организации с целью использовать ее членов для нелегальной контрреволюционной работы.

Разрабатываемый Бельским РО по делу формуляр МЯЛКОВСКИЙ Виктор Матвеевич 1902 года рождения, учитель школы №-2 гор. Бельска. За активную работу в «ОЗОН» был польским правительством дважды награжден.

Жена МЯІКОВСКОГО источнику «Петров" рассказала: «Мой муж МЯЛКОВСКИЙ восстановил организацию «Коло молодых поляков в несения помоци», в которую втягивают молодежь для сбора денег, которыми оказывают помощь нуждающимся полякам в частности высланным и скрываюцимся от репрессий.»

Называя уже работаюцих в этой организации дочь учителя Кани, Барановского и Улячика МЯЛКОВСКАЯ заявила: -

«Вот они служат в гражданском госпитале города Бельска и там имеют большую возможность проводить эту работу среди приезжаюгцих крестьян, а в праздные дни это мероприятие проводится в костеле.»

При отсутствии должного контроля за работой учителей в школах со стороны Отдела Народного Образования, контрреволюционно-националистический элемент в практической работе направляет воспитание учацейся молодежи в антисоветском духе.

Отдельная часть преподавательского состава проводит изучение исторического художественного материала, оторвано от революционной классовой борьбы.

Ломжинской СШ №-1, учитель ЛЮБОВИДЗКИН при разборе 2-й части «Дедов" произведения Мицкевича, не заострил внимание на революцион- 
ном содержании и не подчеркнул, что Мицкевич отражает в своем произведении бунт крестьянских масс против помещиков, а обратил внимание только на стиль и форму произведения.

В Замбровском районе, Выгодской НСШ учитель ДОН читал ученикам 2-го класса статыо из "Вольной Ломжи» подчеркивая гнет в панской Польши общей фразой, не иллюстрируя наглядными примерами классового гнета из жизни родителей учащихся.

В городе Белостоке, в Пединституте, зав. кафедрой физмата - ЛЮБЕЛЬСКИЙ проявляет националистические тенденции к студентам евреям, выставляет искуственно повышенные оценки знаний, ходотайствовал о выдачи 8 стипендий для студентов евреев, тогда как они по своей усвояемости не имели право ее получать. На кафедре был поставлен вопрос о сокраццении одной штатной единицы преподавателя. ЛЮБЕЛЬСКИЙ выступил с такой речью: -

«Одному из нас придется голодать», дальше добавил: «Я своих часов не отдам, я хочу жить.»

В этом же институте зав. кафедрой иностранных языков БУРГИН по нац. еврей, кафедра состоит из 7 человек, из них один поляк, остальные евреи. БУРГИН добивается увольнения из института члена своей кафедры учителя поляка НОАКА, по мативам что как-будто плохо читает лекции. На самом деле НОАК лучше читает чем ХАНИНА и ГЕФОН преподавательници еврейки этой кафедры.

Среди учителей и учащихся средней школы №-3, города Белостока, в феврале 1941 года, по инициативе учительницы СЕНАБРАЦКОЙ был произведен сбор денег для оказания материальной помощи высланным семьям.

СЦЕКОВСКИЙ Владислав офицер резерва 6. польской армии, учитель польского языка 13-й школы г. Белостока, устраивал в своей квартире сборища учеников старших классов среди которых заявлял: -

«При Советской власти полякам стало жить тяжело, их везде притесняют, насильственно уничтожают польскую культуру стараясь провести русификацию.»

СУЛКОВСКИЙ арестован и виновным себя в этом признал.

МИЛЕВСКАЯ учительница дер. Липки, Сопоцкинского р-на в октябре 1940 года в организованном порядке привела из костела в школу родителей которые потребовали закрыть русскую школу мативируя невозможностью в таковой преподавать религию. 
В личной беседе с агентом МИЛЕВСКАЯ заявила: -

«Мы поляки ни когда не откажемся от своей веры и обычаев. Я ни за что не поверю чтобы Польша погибла как государство»

Учительница этой же школы СЕМЕЛЬКО с учениками 5-го класса разучивала религиозно националистические песни. После урока ученики запели Советскую песнь которую СЕМЕЛЬКО прервала заявлением «Здесь польская школа и петь русские песни нельзя.»

В результате такого направления воспитательной работы среди учащихся многие из них вышли из пионерской организации подтвердив о своем стремлении посещать костел.

Учительница школы №-2 г. ЦЦучино, Граевского района - ЧАЙКОВСКАЯ в 1940 учебном году при указании РОНО об из'ятии учебника 6. польской истории, учацимся заявила: -

«Дети эту книгу теперь изучать не разрешают, отложим ее пока до своей поры.»

ПШИБЛОВСКАЯ учительница Сребренской школы, Снядовского района в 1940 году пыталась-начала готовить для постановки в клубе силами учащихся школы, контрреволюционную националистическую пьесу «Жид сват».

Такое воспитание находит свое отражение среди учащейся молодежи. В средней польской школе №-5 гор. Белостока, вновь назначенный директор ПЕНЯНСКИЙ потребовал от учителей проведения мероприятий по укреплению дисциплины в школе, что последние встретили с явным нежеланием. В знак протеста и поддержание настроений учителей, 19 учеников 8 класса подали в Гор.ОНО коллективное заявление с просьбой перевести их 3-ю школу мативируя тем, что их не удовлетворяет качество преподавания в 5-й школе. ІІредварительно указанная группа к урокам истории и конституции совершенно не готовилась.

В процессе уроков когда учитель начинает говорить о достижениях СССР, поднимают шум и смех в классе и бросают реплики «Это не наша родина". Актив этой группы учеников, как бывшие члены "харцерства" взяты Белостокским Горотделом УНКВД в разработку.

9/II-41 г. ученики 10-го класса 12-й польской средней школы гор. Белостока отказались принять участие в лыжном городском кроссе. Принявшему же участие в кроссе ОНИЩУК на следующий день в школе весь 
класс об'явил бойкот и наносились всяческие оскорбления. Инициаторов бойкота и насмешек $\mathrm{k}$ ОНИІЦУК - учеников МОТЫЛЕВСКОГО и ІІЕНЧУКОВСКОГО педсовет исключил из школы.

Характерно однако то, что многие из учителей при обсуждении этого вопроса не приняли ни какого участия.

1 -го ноября 1940 года в котолический праздник в пाколах Ломжинского района отсутствовало свыше $50 \%$ учащихся.

В Августовском районе в НСII в дер. ІІониве, где зав. Михаловский 1-го ноября 1940 года учащиеся в школу не явились.

В Ломжинской еврейской HCIII №-7 и в Тыкотинской НCIII Белостокского р-на, имеются несколько учащихся, которые систематически посещают школу по субботам и в другие религиозные праздники.

В Августовской еврейской НСШI №-5 имели место случаи отказа со стороны учащихся писать в субботу или другие религиозные праздники.

В Граевской средней школе №-1 на религиозный праздник «Рождество» на занятия в школу явилось 211 учеников из 540 , т.е. $39 \%$, а в 5-й средней школе пятый класс отсутсвовал полностью.

В Снядовском районе в ряде школ, т.е. Снядовской, Люботинской, ІІисковской, Лончинской и других имели место факты порчи портретов руководителей партии и правительства.

Все это тщательным образом укрывается от заведывающего РОНО.

Нарушая принцип коммунистического воспитания детей в школе, к-р националистический элемент пытается тем самым дискредитировать Советскую школу в глазах местного населения: -

«В ноябре 1940 года учитель дер. Олдаки, Снядовского района КОМАРНИЦКИЙ Александр, в прошлом офицер белой армии избил по голове Ученика СТЕПНОВСКОГО.

В дер. Зебры Граевского р-на, учительница начальной школы МАЕВСКАЯ во время уроков открывает окна, дети зябнут и при попытке подойти $\mathrm{k}$ печке погреться, МАЕВСКАЯ бъет их по лицу рукой и ставит на колени.

Директор Трошинской НСІШ, Снядовского р-на - ВЛАССОВСКИЙ, на религиозный праздник «Вшистки свенты» устроил не рабочим днем школы и все ученики ходили в костел.

Успеваемость учащихся в этой школе за первое полугодие составляет $74,6 \%$.

ВЛІАСТОВСКИЙ разрабатывается как участник к-р повстанческой организации. 
Разрабатывается по связям с руководителями повстанческой организации ГАЙЛУПЕНЯ Михаилом Михайловичем по агентурному делу "Ожидающие», прибывшая из восточных областей и работающая зав. начальной школы в дер. Тарнополь, Луковского сельсовета, Свислочского р-на, КРУТОВНЕВА Ираида Михайловна, 1924 года рождения, уроженка ст. Орша, Оршанского р-на, Витебской области БССР, член ВЛКСМ, образование неполное среднее, антисоветски настроена, среди населения ведет такте разговоры: -

«Когда я была на курсах учителей, то в то время я была полуголодной, что ни чего нет, а в колхозе моя мать живет и та сидит без хлеба.»

Учительница КУЛЬБА, Августовского района, в письме к своим родителям писала: -

"Я переживаю такой ужас и кашмар, что ни рада, что сюда попала, не знаю переживу или нет. В магазинах кроме кофе ни чего нет. Народ Советской властью не доволен, уходят в лес и там занимаются бандитизмом. Ежедневно растреливают десятки и все молодежь...»

Крайне неудовлетворительно поставлено дело с повышением идейнополитического уровня учительского состава, а также с повышением квалификации и оказании повседневной конкретной помощи в их работе.

Необходимо учесть, что по области работают 2950 учителей не имеющие педагогического образования, которые окончили краткосрочные учительские курсы. Кроме того большинство учителей имеют полугодовой опыт работы в Советской пколе и безусловно слабо ориентируются в методах коммунистического воспитания и к тому же не освободились от прежитков капитализма. Поэтому методическую и массово политическую работу среди учителей должны проводить районные парткабинеты, чего в ряде р-нов нет.

Плохо развернули свою работу педкабинеты в Чижеве, Свислочи, Заблудове, Августове. Не открыты педкабинеты в следующих районах: - Сапоцкинском, Домбровском и Ломжинском.

Открывшие педкабинеты далеко не удовлетворяют своим требованиям, как-то Соколковский педкабинет, где зав. педкабинетом СПЕКТОР, знаюций педагогическое дело, но не желает настойчиво и заботливо относиться к своей работе, а именно помецение не удовлетворяет требованиям педкабинета, комнаты в 16 кв. метров без обстановки и оборудования. Материал педкабинета составляет пустые папки лежацие на столе и на 
стене висит одна карта русского княжества 18 века, больше ни чего. Нет также и учета о проделанной работе.

Изучение краткого курса Истории ВКП(б) учителями проходит индивидуально и отдельные Райкомы КП(б)Б не уделяют должного внимания, как-то секретарь Райкома КН(б)Б, Заблудовского района постоянно дававший обещание помочь в оказании консультации по изучению истории ВКП(б), до сих пор ни чего не сделали.

IІриняты меры к активизации агентурной разработки к-р националистической интеллигенции и РО НКВД даны конкретные указания по существу.

\author{
НАЧАЛЬНИК УНКГБ ПО БЕЛОСТОКСКОЙ \\ ОБЛАСТИ - ПОЛКОВОЙ КОМИССАР - \\ (БЕЛЬЧЕНКО) (podpis)
}

НАЧ. 2 отдеЛа УНКГБ по Б/О

СТ. ЛЕЙТЕНАНТ ГОСБЕЗОПАСНОСТИ (К А Ц Е B) (podpis)

13 марта 1941 года

№ $\underline{2 / 995}$

гор. Белосток. ${ }^{c}$

Oryginal, maszynopis.

Źródło: PAOSOG w Grodnie, zesp. 6195, spr. 1, t. 189. k. 93-109.

$\mathrm{Na} 1$ stronie dokumentu u góry z lewej strony ukosem adnotacja odręczna zielonym atramentem: "Wpł. 17.III.1941 r."

- Podkreślenia i wielkie litery oryginału.

'Slowa: "чего в ряде р-нов нет" wpisane odręcznic.

' Dzień i nr wpisane odręcznic. 


\title{
Dokument 15
}

1941 maj 12, Bialystok, - Raport specjalny Zarzq̨du Obwodowego NKGB obwodu białostockiego o antyradzieckich wystapieniach $w$ zwiazku $z$ akcją odbierania kułakom nadwyżek ziemi ponad ustalonq normę.

Совершенно секретно

\section{СЕКРЕТАРЮ БЕЛОСТОКСКОГО ОБКОМА КП(б)Б}

\author{
тов. КУДРЯЕВУ
}

\section{С П Е Ц - С О О Б Е Н И Е}

Об антисоветских проявлениях в связи с регулированием норм землепользования.

В связи с установлением предельных норм землепользования и отрезки земли с кулацких хозяйств, заметно активизировалась антисоветская деятельность со стороны к-р кулацкого элемента.

В основном к-р деятельность кулацкого элемента сводится к усиленной агитации о близости войны и "скорой смене власти", которая должна будет привести к "отмене" закона о нормах землепользования, сопровождая агитацию запугиванием бедноты, которая «поплатиться после поражения Советской власти и восстановления Польши».

Активных проявлений при проведении работы по отрезке земли от кулацких хозяйств не отмечено, однако в одном случае в Едвабновском районе к-р повстанческий элемент высказывается об открытых выступлениях в период работы по непосредственной отрезке земли у кулаков.

Наиболее характерные факты приводим ниже:

Кулак деревни Выпихи, Менжинского с/совета, Снядовского района ЭМИЛИТА Болеслав, распространяя провокационные слухи среди бедняков, во время отрезки у него земли - заявил:

«Это было и раньше, как будто давали земельные наделы бедноте, а вышло так, кому раньше дали землю, то их теперь арестовали и вывезли в Россию. Так будет и теперь, как восстановится Польша, то тех кто будет наделен землей арестуют». 
СПРАВКА: ЭМИЛИТА взяТ в активную разработку.

Кулаки дер. Домбик, Снядовского района ХОРОМАНСКИЙ Јюдвиг ХРАСТОВСКИЙ Адольф, беседуя в присутствии нашего источника - высказали:

«Если бы порезать этих бедняков, так и землю от нас не отрезали бы. Вот Польша восстановится, так мы их всех перевешаем».

СПРАВКА: ЭМИЛИТА Болеслав, ХОРОМАНСКИЙ Л. и ХРОСТОВСКИЙ Ад. взяты в разработку.

4 мая с.г. кулак дер. Гуты-Подденки, Грабовского с/совета, Кольновского р-на БЕДЖИЦКИЙ Антон, находясь в кооперативе, среди группы кулаков - заявил:

«Хотя и обрезают у нас землю, но они ей все-равно долго пользоваться не будут, пусть пока утешатся убогие, а вернется наша власть сами отдавать будут».

Присутствующий при этом разговоре кулак деревни Гуты-Старые, того же с/совета ВШЕБОРОВСКИЙ Марцелий Александрович - высказал:

«Пусть отбирают, так долго продолжаться не будет, придет наша власть, тогда расчитаемся".

СПРАВКА: БЕДЖИЦКИЙ АнТОН и ВШЕБОРОВСКИЙ Марцелий взяты в разработку.

1 мая с.г. разрабатываемая группа кулацкой молодежи дер. Южец, Едвабновского р-на дОБРОВОЛЬСКИЙ М., СОКОЛОВСКИЙ А. и КОРЛОВСКИЙ С. присутствуя на вечеринке - говорили:

"Скоро советы отсюда уйдут. Германия и Англия окружили весь Советский Союз с Севера и Юга, как ударят по всему фронту, так что и земли не успеют отрезать».

Скрывающие члены к-р повстанческой организации дер. Броново, Едвабновского р-на ГАЛИНСКИЙ Станислав, МЕТЕКОВСКИЙ Юзеф, распространяют слухи о том, что когда будут отрезать землю, они выступят и не допустят этого мероприятия.

СПРАВКА: Даны указания о поимке и аресте ГАЛИНСКОГО и МЕТЕКОВСКОГО.

В целях предотвращения активных проявлений и пересечений всевозможных кулацких выступлений, даны указания начальникам ГО и РО 
НКГБ об усилении агентурной разработки всего учтенного контрреволюционного элемента, приобретение новой агентуры из числа лиц, хозяйства которых подлежат отрезке ных групп и формирований.

На лиц, подготовляюцих активные выступления, даны указания о немедленном их аресте и привлечении к уголовной ответственности.

Начальник УНКГБ Белосток. области Майор государств. безопасности (podpis) (БЕЛЬЧЕНКО)

Нач. СПО УНКГБ Белосток. области

Ст. лейтенант госуд. безопасности - (podpis) (КАЦЕВ)

12 мая $1941 \mathrm{r}$.

№ $\underline{2 / 1769}$

гор. Белосток. ${ }^{c}$

Oryginal, maszynopis.

Źródło: PAOSOG w Grodnie, zesp. 6195, spr. 1, t. 189, k. 153-158.

$\mathrm{Na}$ górze dokumentu $\mathrm{z}$ lewej strony prostokątna pieczęć kancelaryjna: ${ }_{n}$ Wpłynęło, $\mathrm{Nr} 1459^{n}$ i niżej: „ 13/V 1941." (Nri data wpisane odręcznic) oraZ adnotacja: „Zapoznać Sekretarıy Obkomu" $i_{n}$ DDorowkon, podpis Kudrjajewa. Niżej pionowo: podpisy Popowa i Spasowa i data 17. V.41 i obok ukosem: podpisy: Anisimowa, Kulbina i Dorowko i data: 21.V.41.

- Podkreślenia i wielkie litery oryginału.

' Słowa: „хозяйства которых подлежат отрезке” podkreślone odręcznic w trakcie czylania.

'Dzień i nr wpisane odręcznic. 


\section{Dokument 16}

1941 maj 12, Bialystok, - Raport pisemny Zarzqdu Obwodowego NKGB obwodu białostockiego o antyradzieckich wystapieniach w zwiqzzk z obchodami święta pierwszomajowego.

\section{Совершенно секретно}

\section{СЕКРЕТАРЮ ОБКОМА КП(б)Б}

тов. КУДРЯЕВУ

\section{$\underline{3 \text { дес }}$}

\section{ДОКЛАДНАЯ ЗАПИСКА}

об антисоветских проявлениях в связи с празднованием 1 мая по Белостокской области.

Со стороны контрреволюционно-националистического элемента в период подготовки празднования 1 мая были отмечены факты активных антисоветских проявлений выразившиеся:

1. В диверсионно-террористических намерениях.

2. В изготовлении, расклеивании и разбрасывании в отдельных районах к-р листовок (Белосток, Гродно, Ломжа, Скидель, Брянск, Едвабно).

3. В вывешивании польских националистических флагов (Крынки).

4. В срыве красных флагов с крестьянского дома.

5. В распространении прогерманских настроений и провокационных пораженческих слухов.

Одновременно заметно усилилась активность католического духовенства - ксендзов (Брянск, Сапоцкино).

Имеюгцаяся агентура мобилизованная на выявление намерений к-p националистического элемента в дни Международного праздника 1 мая установила, что повстанческий элемент в Лапском районе подготавливается - к диверсии над войсковыми частями, а в Граевском районе в день 1 мая ожидается восстание. 
24 апреля источники "Око» и «Змиевский» донесли, что в дер. Злотария, Белостокского района к быв. народовцу МАРТИШЕВСКОМУ Яну приезжал из дер. Мойсики, Лапского района быв. подофицер 42 полка МОЙСИК Вацлав, который рассказал, что в их деревне дело с повстанческой организацией обстоит хорошо, что имеют значительное количество оружия и под 1 мая готовятся наделать панику для воинских частей, расквартированных в деревне Соколы, для чего они хотят по дорогам подложить бомбы с часовым механизмом.

\section{СПРАВКА: МАРТИШЕВСКИЙ Ян арестован, МОЙСИК} устанавливается, по делу ведется следствие.

Арестованный Граевским РО НКГБ по агентурным данным участник к-р повстанческой организации "Отдел Белограндовской партизанки" ЗАГОРОВИЧ ІІавел Александрович о целях и задачах организации на допросе показал:

«Мы, члены к-р повстанческой организации ставим своей целью в случае нападения на Советский Союз какой либо капиталистической державы, поднять в тылу восстание против Советской власти.

Для вооружения участников организации мы наметили напасть на склад с оружием и боеприпасами и вооружить участников организации, после чего мы должны были нападать на воиские части в тылу.

Нападение на склады воиских частей мы наметили в Осовце, ІІодлеске и Гонензы.

В апреле месяце 1941 года в доме ШЛЕВИНСКОГО Хенрика, я - ЗАГОРОВИЧ, ШЛЕВИНСКИЙ и КУЧИНСКИЙ Францишек договорились, что в день 1 мая должно быть организовано восстание нашей организации и в котором необходимо принять участие. Но об этом мы ни-кому из членов организации не говорили».

СПРАВКА: Следствие по делу «Отдел Белограндовской партизанки" продолжается, устанавливается состав организации и наличие оружия с целыо его из'ятия.

2 мая 1941 года в 11 часов утра около деревни Гронды-Старые, Замбровского района, скрывающиеся бандиты братья ВНОРОВСКИЕ обстреляли бедняка КУЛЕША Чеслава и его жену КУЛЕШ Владиславу, которая была ранена двумя пулями в плечо и ее муж получил легкое 
ранение в подбородок (царапина). Бандиты скрылись, розыск которых продол)кается. Следствием пока устанавливаются противоречия в показания $\mathbf{x}$ жены и мужа. Приняты меры к розыску бандитов и их ареста.

30 апреля с.г. в Цехановецкий РО НКГБ поступило агентурные данные о наличии боеприпасов у гр-на дер. Годлевско-Лубы, Древне-Голынского с/совета ЛИПСКОГО Ян Францевича, который после обстоятельного допроса признался о наличии у него спрятанного оружия и боевых патрон.

При производстве обыска в месте указанном ЛИПСКИМ Я. Было из'ято: один револьвер, системы «наган" и 3619 шт. боевых патрон польского образца.

СПРАВКА: ЛИПСКИЙ Ян привлечен к уголовной ответственности и следствие ведется с упором выявления к-р формирования и оружия.

За период празднования в шести местах разных районов области обнаружены к-р листовки в основном содержание их почти одинаковое и носят характер к-р лозунгов о восстановлении Польши.

Характерно, что листовки в большом количестве были выброшены в городах Белостоке и Гродно, причем как и в Белостоке так и в Гродно они выброшены пачкой в одном месте, таким образом их легко было из'ять и предотвратить возможное распространение их.

Малый текст и содержание листовок, стандартная бумага и обычные чернила не являются характерными и затрудняют вылавливание авторов этих к-р лозунгов.

Рапространение контрреволюционных листовок было обнаружено в г. Белостоке, Гродно, Ломжа, в м. Лунна, Скидельского р-на, дер. Закшево, Брянского р-на и дер. Радзилово, Едвабновского р-на.

Из общего количества 131 листовок антисоветского характера, писанньх от руки, было обнаружено в г. Белостоке 41 шт. подброшенных в одном месте около почты и в г. Гродно пачка листовок в количестве 80 шт. были подброшены около здания РО НКГБ и штаба Армии, в остальньх районах были из'яты по 1-8 листовки. Подробности мы донесли своевременно спец-сообщениями.

В порядке агентурно-оперативных мероприятий 2 мая 1941 г. был задержан по подозрению в распространении антисоветских листовок в дер. Радзилово, Едвабновского района БЕЙДЕР Михель Рувинович, 1920 года рождения, еврей, без определенных занятий, житель м. Семятичи, у которого при личном обыске обнаружена одна к-р листовка и кусок теста для клейки. 
Допрошенный БЕЙДЕР М. сознался , что он 19 апреля с.г. получил пачку антисоветских листовок и по заданию участника к-р повстанческой организации в Снмятичах, Брестской области АЛЕКСАНДРОВСКОГО Владика Антоновича, 35 лет, поляка, выехал в города Ломжу, ВысокоМазовецк, Визно, Цехановец, и Радзилово, для расклейки листовок. Со слов БЕЙДЕР он во всех перечисленных пунктах расклеил и разбросал имевшиеся у него к-р листовки.

На следствии БЕЙДЕР назвал себя участником к-р повстанческой организации в Семятичах и назвал ряд лиц соучастников, проживаюгцх на территории Брестской области в связи с чем по требованию УНКГБ, Брестской области арестованный направлен в их распоряжение.

Крестьянин деревни Барглувка, Августовского района КАРПИНСКИЙ Антон Антонович, 1908 года рождения, проходя мимо дома крестьянина тойже деревни КРЯНИНА Герасима, сорвал с дома два красных флага, но был замечен нашим источником.

Арестованный КАРПИНСКИЙ А. в совершенном им преступлении виновным себя признал.

2 мая 1941 года около быв. имения Макаровцы, Крынковского района были вывешены на деревьях 2 национальных польских флага с контрреволюционными надписями.

СПРАВКА: По делу арестована группа в 7 человек, в том числе КАРЛОВСКИЙ Иосиф, подпоручик 6. польской армии, члены контрреволюционной повстанческой организации.

По делу получены показания, что вскрытая повстанческая группа с 1939 года занималась распространением a/c листовок.

30 апреля 1941 года наш источник "Астрахань" донес, что ксендз Брянского костела ЧАРКОВСКИЙ на исповеди используя религиозные убеждения прихожан костела, внушает последним совершение террористических актов над Советским активом, говоря, что: «Никакого греха не будет в убийстве человека, который выступает против религии и агитирует за Советскую власть» - и что он на это дает свое разрешение.

СПРАВКА: Даны указания нач. Брянского РО НКГБ об активной разработке ксендза ЧАРКОВСКОГО. Собрать свидетельские показания и запросить санкцию на арест ксендза. 
В деревне Вышки, Брянского р-на по заданию ксендза НЕДРОШЛЯНСКОГО, крест расположенный на против трибуны для митинга был украшен зеленью и цветами, а в дер. Соничи, Сапоцкинского р-на, где также была трибуна недалеко от креста, местный ксендз установил алтарь. ГІрибываемые крестьяне на митинге собирались у алтаря с которыми ксендз пытался совершить молебен и шествие верующих, что своевременно было предупреждено.

Ксендз деревни Осовец БОЖУХОВСКИЙ узнав, что часть верующих поляков участвовало в первомайских торжествах и пели революционные песни, он при посещении последними костела - заявил:

«Нужно служить кому либо одному, богу или большевикам - говоря: раз вы поете, что - никто не даст вам избавления, ни бог ни царь - то нечего вам ходить в костел и молиться богу».

Экономка ксендза костела св. Роха БУЛАВИЦКАЯ Регина 26 апреля нашему источнику рассказала, что 3 мая в день польской конституции в костелах будет устроен специальный молебен, на котором будут петь торжественный гимн "Боже цось польская".

Кроме этого будет устроен молебен на том месте около вокзала, где была могила "неизвестного солдата".

СПРАВКА: Через Горисполком приняты меры к недопущению молебствий вне костела, а в костеле должна быть проведена обычная служба.

В м. Одельск, Соколковского р-на на первомайском митинге выступил фигурант разработки ГРЕСЬ Эдварт, 1912 года рождения, сын кулака, учитель местной школы, в конце своего выступления сказал: «Да здравствует наш вождь. - ", "Да здравствует наша Армия. - "

Говоря источнику, что его понимают, как он выступает и о ком говорит.

ИзвозчикГлавтекстильсбытаКОЗЛОВСКИЙВикентийКонстантинович 1 мая будучи в ресторане в пьяном виде пел польский гимн, восхвалявший ІІилсудского. (КОЗЛОВСКИЙ взят в разработку).

В м. Щучино, Граевского р-на в день проведения празднования, быв. народовец МЕТЕЛЕВСКИЙ Александр, проходя по улице пел немецкий гимн. (МЕТЕЛЕВСКИЙ взят в активную аг. разработку).

Особо активную деятельность антисоветско-националистического элемента отмечено в распространении прогерманских настроений, различных 
провокационных измышлений о близости войны и поражения СССР, как например:

Житель дер. ІІІюкты, Едвабновского р-на КАРБОВСКИЙ Франц Янович и ЗАРЕЦКИЙ Антон Якубович, среди крестьян деревни распространяют, что:

«Германские войска скоро будут здесь, так как они уже победили Югославию".

Если Германия выступит против советов, то она возьмет не только Белоруссию, а вступит в Москву.

Мы всегда должны быть готовы, как советы начнут уходить, так мы возьмемся за их помоцников-активистов».

СПРАВКА: КАРБОВСКИЙ Ф. и ЗАРЕЦКИЙ А. взяТЫ в Разработку.

Средняк деревни Духны-Стары, Снядовского р-на быв. народовец ЯСТРЕМСКИЙ Юзеф, в беседе с крестьянами той же деревни сказал:

«Мучаемся мы при большевиках, издеваются они над нами, но этого уже долго не будет, скоро придут немцы, тогда большевики побегут как зайцы, при них лучше будет, чем у большевиков».

2 мая быв. торговец м. Снядово КРАЕВСКИЙ Владислав, среди своих знакомых говорил:

«Когда мы будем праздновать 3 мая так, как мы праздновали раньше. Тогда мы чувствовали себя свободно, не боялись, а теперь при большевиках только одни разговоры, обеццают золотые горы, а дела ничего нет. Посмотрите как люди живут в Германии. Хотя немцы и обидели Польшу, но там народ цветет, живут без нужды, народ не запуган, а тут только аресты и пугают выселением».

1.V.1941 года быв. грузчик польских военных складов ЛЕОНОВИЧ Роман в беседе с нашим источником «Ковалевским» сказал:

"Сейчас Германия готовится к войне против СССР, она хочет ударить с Финляндии и Венгрии. Турция заявила Советскому правительству, что если СССР не об'явит войну Германии, то Турция не будет терять своих пюдей и сама пропустит германские войска.

Тогда Германия ударит на СССР в первую очередь на Баку, откуда войска пройдут через Турцию». 
Бывший старший сержант польской армии КРАХ Ян Карлович нашему источнику 1 мая сказал:

"28 апреля с.г. я слушал радио из Лондона, где говорилось, что Германия готовится к захвату Советской Украины и Кавказа, а потом Египта и Палестины.

Это только поддерживает мое желание жить далыше».

СПРАВКА: КРАХ Ян, Леонович Р., Краевский В.

и Ястремский Ю. взяты на аг. разработку.

Начальник УНКГБ Белосток. области

Майор государствен. безопасности - (podpis) (БЕЛІЬЧЕНКО)

Нач. СПО УНКГБ Белосток. области

Ст. лейтенант госуд. безопасности - (podpis) (КАЦЕВ)

12 мая 1941 r.

№ $\underline{2 / 1768^{b}}$

гор. Белосток.

$\mathrm{Na}$ górze dokumentu $\mathrm{z}$ lewej strony prostokąına pieczęć kancelaryjna: "Wpłynęło $\mathrm{Nr}$ 1460" i niżej: 13/V 1941" ( $\mathrm{Nr}$ i data wpisane odręcznie) oraz ukosem adnotacja: „Lapoznać Sekretarzy Obkomu" i podpis Kudrjajewa. Obok i niżej podpisy: Anisimowa, Elmana, Kilbina, Popowa i Sawałowa oraz daty: 18 V 41, 20 V i 21.V.41.

Oryginał, maszynopis.

Źródło: PAOSOG w Grodnie, zesp. 6195, spr. 1, 1. 189, k. 159-167.

- Podkreślenia i wielkie litery oryginału.

' Dzicń i nr wpisanc odręcznie. 


\section{Dokument 17}

1941 maj 15, Biał ystok, - Kolejny raport specjalny Zarzqdu Obwodowego NKWD obwodu białostockiego o przebiegu akcji odbierania kułakom nadwyżek ziemi ponad ustalona normę! .

\section{СЕКРЕТАРЮ ОБКОМА КІІ(6)Б \\ тов. КУДРЯЕВУ. - \\ гор. Белосток. -}

\section{СПЕЦ.СООБЩЕНИЕ}

О ходе работы по отрезками излишков земли у кулацко-зажиточной части населения.

В процессе проведения данного мероприятия среди кулацкой части населения зафиксировано ряд антисоветских выступлений, так: -

В Кнышинском районе, в дер. Зутелец, Тростьянского с/совета, в доме депутата с/совета проводилось собрание по вопросу отрезки земли, где выступил ПАЗОВИЧ Иван Юльянович, последний сказал: -

"Что со стороны бедняков заявления подавать не нужно на просьбы земли, так как за эту землю придется платить большие налоги по 8002000 рублей. Кроме того за нее вас всех загонят в колхоз, где будите голодать и вместо хлеба будите есть траву, как это делается в России, и будите есть человек человека. Если Вы хотите земли, то отдайте вы мне свои налоги, а я отдам свою землю".

В результате такого выступления в той же деревне подали заявления на получение земли только два человека.

СМОЛЕЙ Антон Максимович, житель дер. Колосы, Гричевического c/c, Свислочского района, среди бедняков заявил: -

«Мою землю никто не возмет, а если кто посмеет взять, то с тем будет расчет короткий. Кроме того им же было заявлено депутату сельского совета тов. ШЕВЧУК, что Ваша Советская власть не стоит полбутылки молока, вот придет время, я вас всех перевешаю, за то, что Вы являетесь представителями этой власти", и с ножем в руках выгнал из своего дома депутата сельского совета тов. ШЕВЧУК.

В этой же деревне СМОЛЕЙ Яков Александрович в беседе с Будницким заявил: - 
«При поляках мы мучились и сейчас нам наверно свету не видать, с крестьянина дерут десять шкур, а сейчас еще думают отрезать землю. Это все ведет к тому, чтобы крестьянство уничтожить, или заставить его жить как нищий. Такой политикой как у советов еще не видал мир, ибо это народное страдание».

ПРИЛОЖИНСКИЙ Иван Михайлович, житель дер. Горбары, Луковского сельсовета, в беседе с депутатом своей деревне, говорил: -

«Теперь землю у кулаков забирают, но эта земля будет пустовать, не засеянной потому, что в колхоз никто не пойдет, а крестьянинединоличник не возмет».

ЖУКОВСКИЙ Александр, житель дер. Войтик, Андреяновского с/совета, в присутствии членов комиссии заявил: -

"Что вы думаете, здесь будут большевики?», а затем обозвал членов комиссии «собаки».

На ряду с проведением данного мероприятия по ходу отрезков земли, следует отметить факты содействия депутатов сельских советов кулакам, которые вместо оказание помощи комиссии сами стали на защиту кулацкой части населения, как например: -

В дер. Селыцы депутат сельского совета ВРУБЛЕВСКИЙ Иосиф отказался в присутствии комиссии производить отрезки земли у кулака Жуковского в тот день когда было предложено комиссией.

Вместо празднования 1-го Мая, Врублевский совместно с кулаком Жуковским произвел отрезки земли по его личному усмотрению без участия комиссии.

Кроме указанных фактов также имеются случаи, когда кулацко-зажиточный элемент узнав, что происходит отрезки земли, приступили к массовой вырубке леса, в Лапском районе.

\section{Зам НАЧАЛЬНИК УПРАВЛЕНИЯ НКВД БЕЛОСТОКСОЙ ОБЛАСТИ - КАПИТАН ГОСБЕЗОПАСНОСТИ (ФУКИН) (podpis)}

№ 53

15/V-41.

Белосток 
Na górze dokumentu z lewej strony prostokątna pieczęć kancelaryjna: „Wpłynçło Nr 1521" i niżej "16/V 1941", podpis Kudrjajewa oraz ukosem: „Zapoznać tow. Popowa, Dorowko”. Po podkreśleniu podpis Dorowko.

Oryginal, maszynopis.

Źródło: PAOSOG w Grodnie, zesp. 6195, spr. 1, t. 189, k. 175-176.

- Wielkie litery i podkreślenia oryginału.

'Stowo: „Зам" wpisane odręcznie i podpis 7astępcy luukina.

' Wpisane odręcznie.

'Por. dok. 15, 212 maja 1941 r.

\section{Dokument 18}

1941 maj 22, Bialystok, - Kolejnyt raport specjalny Zarzqdu Obwodowego NKGB obwodu białostockiego o antyradzieckich wystapieniach $w$ zwiqzzku $z$ akcja odbierania kułakom nadwyżek ziemi ponad ustalong normę.

\section{Совершенно секретно}

\section{СЕКРЕТАРЮ БЕЛОСТОКСКОГО ОБКОМА КП(б)Б}

\section{тОв. КУДРЯЕВУ}

\section{С П Е Ц - С О О Б Ц Е Н И Е}

Об антисоветских проявлениях в связи с регулированием норм землепользования.

Проявление активных действий и антисоветской провокационной агитации в связи с регулированием норм землепользования, за последнее время значительно усилилось.

Отмечены ряд фактов, когда к-р настоенная кулацкая часть деревни стала на путь активных противодействий проводимым мероприятиям по отрезкам земли. 
В отчетном периоде выявлены факты, что в отдельных случаях к-p кулацкому элементу, путем угроз и запугивания удается распространить свое влияние на отдельных бедняков, которые отказываются от прирезанной им земли.

Запугивание бедноты со стороны к-р кулацкого элемента проводится путем угроз убийством, поджогом и расправой «При восстановлении Полыни".

8 мая 1941 года бедняк деревни Плисновцы, Сапоцкинского района ЗАЛЕВСКИЙ Вацлав, получивший участок земли отрезанный у кулака СЕРПИНСКОГО Зигмунда, выехал в поле на обработку, в это время подошел к нему зять СЕРПИНСКОГО 3. - САНЧУК Иван Осипович и предложил удалится с поля. ЗАЛЕВСКИЙ В. отказался и заявил, что «Этот участок земли принадлежит ему и получил он его от государства».

САНЧУК Иван тут же схватил ЗАЛЕВСКОГО В. за воротник и нанес удар камнем по голове.

СПРАВКА: САНЧУК И.О. Сапоцкинским РО НКГБ арестован, с привлечением к уголовной ответственности по 106 п. 2 УК БССР. Нами даны указания закончить расследование в 3-х дневный срок и договориться с местным прокурором о проведении показательного процесса над обвиняемым.

В этом же районе в деревне Лихоселықы была произведена отрезка земли у кулака ПРОЛЕЙКО Антона, который совместно со своим другом МАКАРЕВИЧЕМ Викентием, вошли в дом члена комиссии по отрезки земли РОМАНЧУКУ Викентию и стали угрожать принятием мер к их выселению из деревни. После чего ПРОЛЕЙКО А. и МАКАРЕВИЧ В. направились в дом другого члена комиссии ЭКСТЕРОВИЧУ, которому стали угрожать:

"Мы вас прижмем так, что сыворотка потечет».

После указанных угроз, направленных против членов комиссии по отрезке земли, кулак ПРОЛЕЙКО А. ушел домой, а МАКАРЕВИЧ В. направился вторично в дом РОМАНЧУКА Викентия, которому стал угрожать поджогом дома.

СПРАВКА: МАКАРЕВИЧ В. Сапоцкинским РО НКГБ арестован и привлечен к уголовной ответственности.

Кулак дер. Олексино, Олексинского с/совета, Брянского района МОЧУЛА Людвиг, беседуя с женой нашего источника, заявил последней, что: 
«Если кто возьмет у него отрезанную землю, он убьет того».

CIIPAВКА: МОЧУЛА Л. совершил попытку нарушить госграницу, где и был задержан Цехановецким РО НКГБ.

12 мая с.г. кулак дер. Чае-Вулька, Коритинского с/совета, Брянского района - БРИЦ Мячеслав Брониславович заявил нашему источнику:

"Если государство хочет наделять землей безземельных, то пусть землю у меня купит и наделяет. Использовать нашей земли им не придется, придут немцы и тогда все те кто забирал у нас землю будут повешены».

СПРАВКА: Даны указания нач. Брянского РО НКГБ об активной разработке кулака БРИЦ М.

Кулак дер. Эмелиты, Снядовского района КОНОПКО Игнат, беседую в группе односельчан в присутствии нашего источника - сказал:

«Бедняки не могли себе заработать земліо, а теперь хотят работать на чужой, это воры-бандиты, хотят на человеке ехать, но не долго так будет нам, за нашу кровь придется им поплатиться своей жизнью».

КОНОПКО И. настолько озлоблен отрезкой у него земли, что даже категорически отказался от подписи в акте.

СШРАВКА: КОНОПКО И. разрабатывается Снядовским РО НКГБ.

Кулак дер. Колосы, Грицевичского с/совета, Свислочского района СМАЛЕЙ Антон Максимович, по национальности белорусс, в группе крестьян заявил:

«Если кто посмеет взять мою землю, то с тем расчет будет короткий».

СПРАВКА: СМАЛЕЙ Антон взят в активную разработку.

Наряду с активными действиями кулацкой части деревни, направленных против проводимых мероприятий по урегулированию землепользования, отмечены факты запугивания крестьян-бедняков и распространение различных провокационных слухов, так например:

В мая месяце с.г. кулак ШИМБОРСКИЙ Александр в помещении Яблонского с/совета, Лапского района крестьянину ЧЕРНОВСКОМУ заявил:

"Кто сейчас будет брать отобранную большевиками землю, тому мы, как восстановится Польша не простим». 
Кулак м. Сураж, Лапского района БОРОВСКИЙ Михаил, быв. народовец в беседе с крестьянином СЛИЕНКО Кисофон - сказал:

"Советы хотят отнять у нас землю, которую мы добыли потом и кровью, но это еще не известно как будет, мы этим летом будем из большевиков кишки мотать. Я говорил с нашими бедняками, они не возьмут этой земли. Я их хорошо предупредил, что когда восстановиться ІІольша, так тому, кто возьмет землю мы не простим».

СПРАВКА: Кулаки ШИМБОРСКИЙ А. и БОРОВСКИЙ М. взяТЫ Лапским РО НКГБ в активную разработку.

Кулак дер. Лубы, Древно-Голынского с/совета, Цехановецкого района ГАДЛЕВСКИЙ Адольф Адамович, нашему источнику заявил:

"Советская власть забирает у нас землю, но это не надолго, скоро они от нас уйдут и землю нам возвратят, а с теми кто эту землю берет мы жестоко расправимся".

СПРАВКА: ГАДЛЕВСКИЙ А. разрабатывается Цехановецким РО НКГБ.

В результате приведенной антисоветской-провокационной агитации, отмечены факты отказа брать землю, представляемую государством, так:

Бедняк дер. Элимиты, Снядовского района дОМБРОВСКИЙ, не имеюций земли, нашему источнику сказал:

«Мне нужна земля, но брать ее боюсь. Вот будет перемена власти, так они начнут нам мстить. Лучше не лезть к ним».

Бедняк дер. Олексино, Олексинского с/совета, Брянского района КАЛИНОВСКИЙ Казимир, беседуя в присутствии нашего источника - сказал:

«Есть у меня 0,25 га и хватит мне, а если я возьму отрезанную землю у кулака, да еще власть переменится, так он за эту землю убьет меня».

В Липском с/совете, Сапоцкинского района было отрезано 8 га земли ранее принадлежащая ксендзу и роздана беднякам ДРАЙЧУК А., ВРУБЛЕВСКОМУ А. и БАРАНОВСКОМУ О., которые отказались ее принять, так как последних верующая часть убедила, что землю принадлежащую ксендзу может обрабатывать только он. 
По существу активных антисоветских действий кулачества направленных на дискредитацию мероприятий по отрезкам земли, считаем необходимым предложить областному прокурору, дать указание местам о расследовании дел в 3-х дневный срок и проведение показательных процессов обвиняемых

Начальник УНКГБ Белосток. области

Майор государств. Безопасности - $\quad$ (podpis) (БЕЛЬЧЕНКО)

Начальник СПО УНКГБ Белосток. обл.

Ст. лейтенант госуд. безопасности - (podpis)

(КАЦЕВ)

Исп. Шибалов.

22 мая 1941 года

№ 2/1907

гор. Белосток.

Na górze dokumentu z lewej strony prostokątna pieczęć kancelaryjna: „Wpłynęło Nr 1636 ” i niżej 24/V $1941^{n}$ (Nr i data wpisane odręcznie).

Oryginal, maszynopis.

Źródło: PAOSOG w Grodnic, zesp. 6195, spr. 1, t. 189, k. 178-182.

\footnotetext{
- Podkreślenia i wielkie litery oryginału.

b Dzien i nr wpisane odręcznie.

' Por. dok. 15, 212 maja 1941 r. i dok. 17, 215 maja 1941 r.
} 


\title{
New Soviet documents on attitudes of the population and the Polish Underground Independence Movement in Białystok district in 1940-1941
}

\begin{abstract}
Summary
A collection of published materials contains 18 documents from Soviet archives created by local organs of USSR's secret police that have been kept confidential until now. They concern various forms of people's social resistance against Soviet policy aiming at sovietization and russification of Poland's eastern lands seized in result of military aggression of 1939. These documents prove the existence of strong resistance against soviet policy and various forms of activity of the Polish Underground, including military actions. NKGB's reports on agents operations aiming at liquidation of the Underground dominate among the documents, as well as reports on anti-soviet activity of intelligentsia, hostile speeches made during numerous events, holiday celebrations, local authorities election or activity connected with reclaiming land in excess of the established level from kulaks. These documents contain many facts and descriptions of events, some of them in detail, as well as evaluation of these events by the authorities.
\end{abstract}

\section{Новые советские документы о поведении населения и польском национально-освободительном подполье в белостокском регионе в 1940-1941 гт.}

\section{Резгоме}

Публикуемый подбор включает в себя 18 документов из секретных до этого времени советских архивов, составленных местными органами служб безопасности СССР. Они касаются различных форм общественного сопротивления населения советской политике, направленной на советизацию и русификацию территории восточной Польши, занятой в результате вооруженного нападения в 1939 г. Они документируют существование в белостокском регионе сильного сопротивления советской политике, а такке различные формы деятельности польского подполья, в том числе и вооруженную 
деятельность. Среди документов преобладают донесения НКГБ о агентурнооперативной деятельности, направленной на уничтожение подполья, а также сообщения о антисоветской деятельности интеллигенции, враждебных выступлениях во время многочисленных акций, праздников, выборов в местные органы власти, или же о действиях, связанных с отрезкой у кулаков излишков земли сверх предельных норм землепользования. Документы содержат многие факты и описания событий, иногда очень подробные, а также оценки этих событий властями. 